\title{
Competing for the leading role: trials in categorizing greenhouse and energy auditors
}

\author{
Shirley Geyi Xu*, Keele Business School, Keele University, Staffordshire, ST5 5AA, UK \\ Brian Andrew, School of Accounting, Economics and Finance, University of Wollongong, NSW \\ 2522, Australia
}

\begin{abstract}
This paper considers the inter-professional rivalries that took place as the Australian federal government attempted to register a pool of greenhouse and energy auditors and establish a multidisciplinary team structure for emissions-related reporting and trading schemes from 2007-2019. Drawing on the notions of trials (Callon 1986; Latour 1987) and criticism in trials (Bourguignon \& Chiapello 2005), we show how the government's attempts in classifying and determining expert roles and responsibilities from engineering, environmental, and financial backgrounds - with a preference for Big 4 accountants in leadership roles - triggered a series of multi-lateral trials of strength and responsibility, and essentially failed to meet its original purpose. By following the regulatory process, we articulate how terminology and measurement devices were mobilised by the regulator to enrol mixed expertise. We also examine how the envisaged identities, roles, and responsibilities were received by lobbyists from the three expert groups, and then how their concern, criticism, and resistance were acted upon and reacted to by the regulator. Our study reveals the dilemma the non-expert government faced in mediating the conflicting interests and goals of the three expert groups while fulfilling its regulatory and administrative roles. Our analysis shows how accountants' supervision style of delegating technical work and routines to subordinates evoked further controversy. The study contributes to our understanding of how trials between conflicting claims and criticisms influenced the shaping of auditor identities and responsibilities. The lessons learned in Australia provide useful insights into many other regulatory regimes in multidisciplinary fields.
\end{abstract}

4 Keywords: greenhouse and energy audit, trials of strength and responsibility, categorisation and enrollment, criticism and claims of bias

*Correspondence author $\underline{\mathrm{s} . x u @ k e e l e . a c . u k}$ 


\section{Introduction}

The making of professions has been of interest to a wide range of scholars, many of whom argue that periods of interprofessional competition provide rich insights into the process of professionalisation (Armstrong 1985; Abbott 1988). In this professionalisation process, accountants have played contestable and diversified roles in constructing relevance of expertise and legitimacy in new audit fields (Power 1991; Power 1996; Power 1997a; Power 2003; Gendron \& Barrett 2004; Gendron et al. 2007; Skærbæk 2009; O'Dwyer et al. 2011; Andon et al. 2014; Channuntapipat et al. 2019; Channuntapipat et al. 2020), at times with the intervention of the state (Cooper \& Robson 2006; Suddaby et al. 2007; Malsch \& Gendron 2011; Canning \& O'Dwyer 2013; O'Regan \& Killian 2014; Carter et al. 2015; Canning \& O'Dwyer 2016). This literature has provided further impetus to study the profession's continuously evolving dynamics.

Our paper aims to contribute to the wider body of work through a study of the regulatory process in defining the professional identities, roles, and responsibilities that surrounded emerging greenhouse and energy audit service practitioners, and related controversies in Australia over a decade (2007-2019). After the Labor party came into power and ratified the Kyoto Protocol in December 2007, the Australian government had intended to introduce an emissions trading scheme and establish a climate-related auditor pool to include mixed professional expertise (including technical, environmental, and financial) with a hierarchical multidisciplinary team structure. However, the government demonstrated a preference for according accountants (especially those from the Big 4 firms) a leading role by placing them in the top category. This prompted a series of heated debates about the nature of those audits, the relevant expertise required to conduct them, appropriate and fair criteria in classifying and ranking auditors, and rules in determining their responsibilities.

This study is significant given the inherent scientific and technical uncertainties in measuring emissions (Simnett \& Nugent 2007; MacKenzie 2009; Simnett et al. 2009a; Green \& Li 2012), the historical and ongoing competition and cooperation between accounting and engineering/ environmental practitioners (Power 1997a; Owen \& O'Dwyer 2005; Simnett et al. 2009b; Boiral \& Gendron 2011; Canning et al. 2019; Farooq \& de Villiers 2019), and the growing reliance on external regulation to mediate societal risk (Malsch \& Gendron 2011; Canning \& O'Dwyer 2013; O'Regan \& Killian 2014). We follow the regulatory process and articulate why and how different "interessement devices" (Callon 1986) were mobilised by the regulator to enrol mixed expertise through a categorisation program. We also examine how the envisaged identities, roles, and responsibilities were received and responded to by the representative of the three expert groups, and then how their concern, criticism, and resistance were acted and reacted upon by the regulator (Callon 1986; Latour 1987). Our research reveals the dilemma the regulator faced in mediating the conflicting interests and goals of the three expert groups while fulfilling its regulatory and administrative roles, and the controversies resulting from its compromises. The key actors under our investigation included the Australian government Department of Climate Change (DCC, hereafter referred to as "the Department") ${ }^{1}$, the Australian Auditing and Assurance Standard Board (AUASB), and professional bodies, firms and individual practitioners who represented the interests of accounting, environmental, or

\footnotetext{
${ }^{1}$ In January 2010, this name was changed to the Department of Climate Change and Energy Efficiency (DCCEE). After the greenhouse and energy audit legislation was established, the administrative role was transferred to the Clean Energy Regulator (CER) in April 2012. In March 2013, the DCCEE was abolished entirely (DCCEE 2013). To minimise confusion, we refer to these regulatory functions collectively as the "Department".
} 
engineering experts ${ }^{2}$. By mobilising the concepts of trials of strength, trials of responsibility (Callon 1986; Latour 1987), and criticism in trials (Bourguignon \& Chiapello 2005), our study concerns what happens when conflicting knowledge claims and criticisms from accounting and non-accounting actors meet. We argue that trials were initiated by the Department through a categorisation program to define the identities and allocate the roles of three expert groups, while attempting to resolve the jurisdictional disputes that existed at the periphery of a number of professions (such as accounting, engineering, and science). In doing so, the Department's own identity and regulatory relationship with auditors were also subject to negotiation and extension.

Unsurprisingly, there has been much debate about the applicability and usefulness of financial auditing expertise in emissions-related audit work, most of which highlights the fact that accountants are not trained in science, and would know little about technical measurements and the environmental implications of their audit work (Huggins et al. 2011). Globally, the role of accountants in emissions verification and assurance was also limited, e.g., engineers were the main force under the European Union Emissions Trading Scheme (EU ETS) verification framework. Therefore, "is there a role for assurers from the accounting profession" (Huggins et al. 2011)? And, if so, why (Green \& Li 2012; Zhou et al. 2016)? Our paper further addresses these important questions by also exploring what role accountants can play.

In Australia, although the government intended to rank accounting experts in the top category due to a consideration of the financial implications of the potential emissions trading scheme, engineers and environmental scientists were actively trying to shape the way that greenhouse and energy auditing and auditors would be defined and regulated in order to secure substantive roles for themselves. As Suddaby et al. (2007, p. 333) have argued previously, all three expert groups understood that the commercial implication in these professional practices had been "embraced rather than suppressed". The literature (e.g. Power 1996; Power 1997a; Gendron et al. 2007, p. 101) has shown that compared to its competitors, the accounting profession may be more capable of attaching relevance to its expertise, for instance, through the positioning of claims to auditing expertise as a set of context-free "good practices". This may play a role in subordinating specific expertise from non-accounting professionals. However, little attention has been paid to the nature of the opposition mounted by competing professions and the impact this criticism may have on the audit regulatory process. Our paper considers the ways in which engineering and environmental professions, seeking to establish their role as lead auditors rather than technical experts or members, impacted on the accounting profession within the jurisdictional disputes by testing claims to relevance of expertise and responsibilities, as well as claiming bias of the Department in favor of accountants.

External regulations also create more challenges to accountants as a profession due to lack of social trust because of their past overconfidence in self-regulation (O'Regan \& Killian 2014; Carter et al. 2015). Certainly, resistance to the non-expert government is common in a regulatory space (Malsch \& Gendron 2011; O'Regan \& Killian 2014) in which the Big 4 firms are the leaders in promoting self-regulation; they also have more power and resources to align political interest with the state and influence its decision making (Cooper \& Robson 2006; Suddaby et al. 2007). However, the power relationship between accountants and the state is not static but contingent on trials in a case-by-case basis, as sometimes evidenced by compromise of the state (Malsch \& Gendron 2011), and superficial compliance by accountants on other occasions (Tremblay \& Gendron 2011). More recent studies also showed how the

\footnotetext{
${ }^{2}$ Appendix I provides a full list of abbreviations used in the present article.
} 
regulator sought to establish its legitimacy in dealing with aggressive resistance (Canning \& O'Dwyer 2013; O'Regan \& Killian 2014; Canning \& O'Dwyer 2016). Despite being favored by the Department, there were also conflicts between accountants and the Department, especially regarding the responsibility of team leaders. While previous literature presented how resistance in the regulatory space was acted upon by the regulator (Shapiro \& Matson 2008; Malsch \& Gendron 2011; Canning \& O'Dwyer 2013), the Department, which also designed the trials, had to deal with various forms of criticism (including concern and resistance) from both accounting and non-accounting professions. Therefore, our study concerns the nature of various, even conflicting, criticisms and their influence in shaping the auditing regulatory process.

This paper is structured as follows. The next section provides a more detailed discussion of the theoretical underpinnings of trials of strength and responsibility. Section 3 provides a brief background of the development of greenhouse and energy audit legislation in Australia, thereby setting the actors and scene for the trials. Section 4 outlines the research method adopted in this study. We then present trials in three "episodes" from sections 5 to 7 , offering a brief discussion of each episode at the end of each section. Section 8 provides an epilogue concerning recent changes and implications. We then discuss both the empirical and theoretical contributions of this paper to the accounting literature in our reflection and concluding remarks.

\section{Theoretical underpinnings}

As suggested by Bourguignon and Chiapello (2005), the conceptual apparatus of "trial" was recognised from the work of French sociologists including Bruno Latour (1987) and Boltanski and Thévenot (1999), and is considered to be particularly useful in the analysis of social order and change. Trial of strength is "what happens when forces meet" (Bourguignon \& Chiapello 2005, pp. 673-674; Tremblay \& Gendron 2011, p. 262). As suggested by Bourguignon and Chiapello (2005, p. 669), a trial "refers to the social arrangements organizing any testing of people's abilities resulting in arranging tested people in order" and "( $\mathrm{t}$ )his order makes it possible to allocate social goods". For instance, the accounting literature shows that trials take place when testing the appropriateness of a knowledge claim in a new site (Briers \& Chua 2001; Gendron \& Barrett 2004). Trials also characterize the dynamics of power relationships between the regulator and auditor (Malsch \& Gendron 2011), the fairness of performance measurement systems in testing men's and women's abilities (Bourguignon \& Chiapello 2005), and conflicting logics of compliance and resistance to regulatory discourse and prescriptions (Tremblay \& Gendron 2011). Previous studies suggest that trials of strength are associated with various types of contests, criticism, and resistance, and inevitably result in continuous negotiations, compromises, and identity reconstructions (Briers \& Chua 2001; Bourguignon \& Chiapello 2005; Tremblay \& Gendron 2011). In embedding these ideas of trials into our analysis, we especially link it to controversies in categorisation (Bourguignon \& Chiapello 2005) in the enrolment process (Callon 1986; Latour 1987).

In analysing trials from both Latour (1987) and Boltanski and Thévenot's (1999) perspectives, Bourguignon and Chiapello (2005) suggest that categorisation is important in initiating trials because it aims to transform strengths - legitimate or illegitimate - into recognisable merits. Categorisation requires the criteria to be both controllable and complete. While controllability refers to "what is in the measure and should not be", completeness means "what is not in the measure, but should be" (Bourguignon and Chiapello 2005, p. 689, original emphasis). However, since no categorisation can be designed completely free from bias, the process is inseparable from criticism (Bourguignon \& Chiapello 2005). Bourguignon and Chiapello 
(2005) conceptualised how different forms of criticism could be responded to by the designer of the trial. Their framework on criticism and trial is insightful; however, our setting is characterized by a high degree of complexity in that conflicting criticisms took place at the same time. Given that the Department in our study needed to deal with various forms of criticism (including resistance and concern) from both accounting and non-accounting actors with conflicting interests, criticism such as claims of bias to expertise itself was also subject to trials of strength, as were claims to relevance of expertise.

From the perspective of actor-network theory (ANT), trials in categorisation are tightly coupled with translation. In our case, we were interested in examining the reciprocal and dialectical moments of interessement and enrolment through which the envisaged identities, roles, and responsibilities imposed on the three expert groups were to be tested and stabilised temporarily (Callon 1986; Latour 1987). Based on Callon (1986), we suggest that interessement is a series of proposals by which the primary actor (the Department) sought to allocate experts from the accounting, environmental and engineering professions into different categories with different roles. Interessement is a reciprocal process in which the professional actors also sought to define the nature of the external audits and persuade the Department not to be attracted by competitors' claims (Callon 1986; Latour 1987). Because interessement is related to "translating interests" (Latour 1987, p. 108), it can be achieved by different strategies and devices depending on whether the interests and goals of actors match and the trials of strength between the competing actors. The actor mobilises "values, laws, equivalence conventions" in trials of strength with another actor (Bourguignon \& Chiapello 2005, p. 673). Therefore, the identity of an actor is defined through its attachments and relations with others.

Interessement leads to enrolment if the device of interessement is successful (Callon 1986). Here, enrolment is the outcome of a set of strategies where the Department seeks to define and promote the various identities and roles allocated to the three expert groups through classification. Notably, "enrolment does not imply, nor does it exclude, pre-established roles" (Callon, 1986, p. 10). For Callon (1986), there exists a triangular relationship of A-B-C; if A (the proponent) wants to enrol $\mathrm{B}$ (the target), $\mathrm{C}$ (the competitor of $\mathrm{A}$ ) must be excluded or marginalised. Moreover, for Latour (1987), enrolment is a dialectical process of enrolling others as well as controlling their behavior. This contradiction can only be achieved through a translation of others' interests. However, the three-party relationships were different and more complicated in our investigation. While a competitive relationship existed between B (financial auditors $^{3}$ ) and C (non-financial auditors ${ }^{4}$ ), there was also conflict between A (the Department, the regulator) and $\mathrm{B}$ or $\mathrm{C}$ (financial or non-financial auditors ${ }^{5}$ ). Rather than excluding any competitor, the problem of enrolment in our case was to rank different expertises in order and determine hierarchical roles for the three expert groups. In addition, attributing responsibility is a problem with enrolment; as asked by Latour (1987, p. 118), "how can we decide who did the job"? Therefore, enrolment also deals with "trials of responsibility" (Latour 1987, p. 174).

\footnotetext{
${ }^{3}$ We used the term "financial auditors", "accountants" and "accounting professionals" interchangeably to refer to auditors with financial audit expertise who worked in accounting firms. These auditors are also Registered Company Auditors (RCAs) in Australia.

${ }^{4}$ These included both engineers and environmental auditors who had either technical or scientific backgrounds with experience in environmental audit and/or sustainability assurance, and they worked in non-accounting firms. We sometimes use "non-accountants" and "non-accounting practitioners" interchangeably in contrast to "accountants" and "accounting professionals" in the paper. In particular, engineers are familiar with ISO standards, while environmental auditors are accredited Lead Environmental Auditors (LEAs). Chapter 4 details the differences between engineers and environmental auditors.

5 The word "auditor" was used with a generic sense for practitioners with experience in verification and assurance experience in financial auditing, environmental auditing or sustainability assurance (Owen \& O'Dwyer 2005).
} 
Given the complicated relationship between actors, it is understandable that the Department was subject to criticisms from both accounting and non-accounting actors. In Latour's (1987, p. 202) words, "all actions like 'dividing', 'classifying' or 'ranking' do not do justice due to the unpredictable and heterogeneous nature of the associations". As stated, actors mobilise heterogeneous resources in trials of strength and justice is "just one of them" (Bourguigon \& Chiapello 2005, p. 673).

In the following, we present how trials were problematised from a political need for climate change policy in Australia.

\section{Setting the scene}

As is the way with many significant public policy decisions, Australia's decision to ratify the Kyoto Protocol was part of a suite of electoral promises that took effect immediately after the Rudd Labor Party won the Australian Federal election on 3 December 2007 (AAP 2007; SMH 2007). On the same day, the Department was established as part of the Prime Minister and Cabinet Portfolio (DCC 2007). Along with the ratification of the Kyoto Protocol, the newly elected Federal Government proposed a cap-and-trade emissions trading scheme - the Carbon Pollution Reduction Scheme (CPRS). Over the course of a year, climate change had become central to public policy debates with two significant events in 2008: the Department released the CPRS Green Paper in July 2008, seeking public comment, and the Federal Parliament ratified the National Greenhouse and Energy Reporting (NGER) Act 2007 in September 2008. The aim of the NGER Act 2007 was to introduce a single framework for a national greenhouse gas emissions and energy reporting system (NGERS) to support policy making and help ensure Australia was meeting its international obligations concerning climate change. To reduce the compliance costs of entities, the NGER Act 2007 aimed to replace all the overlapping legacy projects; for example, Greenhouse Challenge Plus ${ }^{6}$, Greenhouse Friendly ${ }^{\mathrm{TM}}{ }^{7}$, the New South Wales Greenhouse Gas Reduction Scheme (NSW GGRS) ${ }^{8}$, the Carbon Disclosure Project (CDP), and the Global Reporting Initiative (GRI) (Australian Government Attorney-General's Department 2007). Both accounting and non-accounting firms had been involved in these projects. For example, while the Greenhouse Challenge Plus was led by environmental auditors (Burritt 1999), the NSW GGRS was conducted by the Big 4 and engineering firms, with the former participating in both the assurance and technical panels. Moreover, financial auditors were involved in an assistance program for emissions-intensive trade-exposed (EITE) industries, developed in advance of the audit framework of the CPRS, and independent of the CPRS and the NGER Act as a whole (DCC 2009a).

Audits served two purposes under the NGER Act, one for NGERS, and the other for the proposed CPRS. Under the NGERS, the reporting obligation commenced in July 2008 for

\footnotetext{
6 The Greenhouse Challenge Plus, which was launched in 1995 under the Howard Government, was a joint voluntary initiative between the Government and industry. The Greenhouse Challenge Plus ceased on 1 July 2009 (http://www.environment.gov.au/archive/settlements/challenge/index.html).

7 The aim of the Greenhouse Friendly ${ }^{\mathrm{TM}}$ initiative was to 1) provide businesses and consumers with the opportunity to sell and purchase greenhouse-neutral products and services, 2) broaden the basis for investment in additional greenhouse-gas abatement, and 3) engage consumers on climate change issues. It was established in 2001 and covered 19 companies. It ceased in 2010.

(http://www.climatechange.gov.au/greenhousefriendly/index.html).

8 The NSW GGRS was one of the first mandatory greenhouse-gas emissions-trading schemes in the world. It was established in 2003 and covered NSW electricity retailers and certain other parties. It ceased in 2012 (http://www.greenhousegas.nsw.gov.au).
} 
entities with over 125,000 tonnes of Scope 1 and Scope $2 \mathrm{CO}_{2 \text {-e }}$ emissions ${ }^{9}$ (large emitters), and the corporate threshold has decreased each year and been maintained at 50,000 tonnes since 2011 in order to meet the international obligation for emissions reduction. The Department instituted the regulatory role of Greenhouse and Energy Data Officer (GEDO), who had the authority to request audits for compliance ${ }^{10}$ or monitoring ${ }^{11}$ purposes, and appoint external auditors (Australian Government ComLaw 2008). For audits under the CPRS, the Department compared different international and national options, such as third-party verification for EU ETS, third-party assurance for NSW GGRS, and the self-assurance model of the forthcoming New Zealand ETS. Finally, in consideration of the potential financial implications, the Department proposed having mandatory assurance on a "risk-based approach" for large emitters prior to submission (DCC 2008a, p. 42), similar to a financial audit. As understood, the measurement of greenhouse emissions is subject to inherent scientific and technical uncertainties. In particular, Scope 1 emissions are subject to greater uncertainty in terms of continuous or accurate measurement, and Scope 2 emissions have to deal with inherent uncertainties regarding emissions factors (MacKenzie 2009; Green \& Li 2012). At the time, the absence of an internationally agreed assurance standard ${ }^{12}$, lack of technical expertise, and potential compliance cost for industry emitters were concerns of the Department (DCC 2008a).

In an effort to fill the gap of an assurance standard, AUASB was asked by the Department to assist in developing auditing requirements under the NGER Act and liaise with the International Auditing and Assurance Standards Board (IAASB) (AUASB 2008). In contrast to the IAASB, which operates under the International Federation of Accountants (IFAC), the AUASB is a government body with a broader mandate (Green et al. 2009; Gay \& Simnett 2015), but most of its members are accountants. In response, the AUASB issued ASAE 3000 Assurance Engagement Other than Audits or Reviews of Historical Financial Information in July 2007, and was planning to issue ASAE 3100 Compliance Engagements in September 2008 (AUASB 2013). These two standards were expected to be incorporated into the NGER external audit instruments (AUASB 2008) and it was expected that all third-party assurance providers would be accredited to ensure a pool of properly trained and qualified providers (AUASB 2008).

To reduce compliance costs, the Department proposed to "align financial and emissions reporting and verification systems for the CPRS" in the CPRS Green Paper (DCC 2008a, pp. 208-209). The proposal was widely supported by the accounting profession, including Ernst \& Young, KPMG, and Grant Thornton, as well as the accounting professional body - CPA

\footnotetext{
${ }^{9}$ Scope 1 refers to direct emissions from sources owned or controlled by the company; Scope 2 refers to indirect emissions such as consumption of purchased electricity, heat, or steam. Scope 3 emissions are indirect emissions other than Scope 2 that are generated in the wider economy. An example is business traveling of an employee from a facility on a commercial airline (DCC 2008c; Simnett et al. 2009a). Due to uncertainty with Scope 3 emissions, it is to be excluded from any assurance engagement (IAASB 2012, p86).

${ }^{10}$ Compliance audits could only be initiated where the GEDO had reasonable grounds to suspect non-compliance, and therefore it might be of a forensic nature. The scope of a compliance audit and the required level of assurance (if any) would differ on a case-by-case basis, and the expense for conducting such audits was to be carried by the reporting entity (Australian Government Attorney-General's Department 2007; DCC 2008b).

11 Audits for other monitoring purposes could be initiated by the GEDO and would be conducted at the government's expense; for example, reviewing industry understanding and use of particular estimation methodologies or the quality controls used by entities to ensure compliance with the NGER Act (Australian Government Attorney-General's Department 2007; DCC 2008b).

12 At the time, only ISO 14064-3:2006 Greenhouse gases - Part 3: Specification with guidance for the validation and verification of greenhouse gas assertions and ISAE 3000 Assurance engagement other than audits or reviews of historical financial information were available; however, neither met the requirement of reasonable assurance engagements.
} 
(Certified Professional Accountants) Australia. In contrast, both the engineering and environmental auditor professional bodies - Association of Consulting Engineers Australia $(\mathrm{ACEA})^{13}$ and the Environmental Institute of Australia and New Zealand (EIANZ) ${ }^{14}$ strongly opposed it. It was clear from the outset that they believed it implied an exaggerated role for financial auditors. In its submission to the CPRS Green Paper, EIANZ stated that they "strongly believe environmental auditors should retain the right to provide sign-off of external audit reports as required under the CPRS" (EIANZ submission 2008, p. 3). Accordingly, the market for professional expertise around climate change concerns was diverse, and consequently, the role of the accounting profession became the "subject of much debate" (Simnett \& Nugent 2007, p. 43). In many ways, through this proposal the Department defined the key actors to be enrolled in constructing greenhouse and energy auditing - the AUASB, financial auditors, environmental auditors, and engineers - but also showed an inclination to place accountants in a more favorable position. This therefore set the scene for the ensuing trials over interprofessional identities, respective roles, and responsibilities within this emerging field.

Figure 1 presents the timeline and milestone events that took place in developing NGER Audit legislations in Australia, accompanied by those that happened at the IAASB and AUASB in developing assurance standards on greenhouse emissions statements. As highlighted, the development of the NGER Audit legislative framework, including the NGER (Audit) Determination 2009 and the NGER Auditor Registration Instrument 2010, involved an extensive consultation process from 2007-2010. While submissions to the CPRS Green Paper have been discussed in this section, Figure 1 highlights three subsequent trials around the consultations and revisions to the regulations. The next section details the data and methods.

Insert Figure 1 here

\section{Data, methods, and actors}

Our key data were sourced from documents produced by the principal actors during the regulatory process over a decade, including government consultation papers, legislations, submissions from the three professional lobbyists, and information obtained from minutes of AUASB board meetings and IAASB roundtable meetings (see Table 1). We obtained most of the documents, including submissions from the websites of the Department ${ }^{15}$ and AUASB (see Table 1). In addition, data were received from interviews with four key representing actors.

Insert Table 1 about here

\footnotetext{
${ }^{13}$ ACEA is an industry body representing the business interests of firms providing engineering, technology, and management consultancy services. There are over 260 firms, from large multidisciplinary corporations to small niche practices, across a range of engineering fields represented by ACEA with a total of some 41,000 employees (ACEA submission 2008).

${ }^{14}$ EIANZ is a professional body that developed a Certified Environmental Practitioner (CEnvP) Scheme for accreditation of environmental practitioners with the Australian Government's investment (EIANZ 2010).

${ }^{15}$ We also contacted the Department in 2010 and obtained all non-confidential submissions for the two most important consultations from 2008 to 2009.
} 
As shown in Table 1, trials happened in three episodes with different purposes. Trial I was initiated by the NGER Act 2007 and CPRS External Audit Consultation Paper (hereafter referred to as Consultation Paper One), published by the Department in October 2008. The Department clearly indicated that it was the "primary mechanism for consultation" (DCC 2008 b, p. 1). In this episode, the Department aimed to classify the roles of technical experts and lead auditors by defining the nature of the external audits. Trials of strength took place among financial auditors, environmental auditors, and engineers by comparing the relevance of their technical, environmental, or financial expertise. After analysing all 39 non-confidential submissions, we filtered out 20 submissions received from the three professional actors. We extensively read and reread the submissions as well as using NVivo to code and categorise the different translations made in the submissions in terms of the nature of "external audit" and the relevant expertise of lead auditors. The coding was also related to their preference for using auditing standards established by ISO or AUASB, or both. For example, it was found that engineers preferred to use ISO standards and accountants preferred AUASB, while environmental auditors preferred both.

Trial II was initiated through the second consultation paper - NGER Act 2007 and CPRS Greenhouse and Energy Audit Framework Overview Paper (hereafter referred to as Consultation Paper Two) in July 2009, which was also announced as the final consultation paper for the NGER Audit legislation by the Department (DCC 2009b). In this episode, the Department aimed to settle interprofessional rivalries through a categorisation program. We analysed 14 non-confidential submissions received from the accounting and non-accounting professions. We paid attention to the way in which the three categories of lead auditors and responsibilities of team leaders and members were proposed by the Department, and linked them to the most controversial issues that aroused wide concern, criticism, and resistance from accounting and non-accounting lobbyists.

Trial III covered a longer period, from the release of the first edition of the two NGER Audit legislations - NGER (Audit) Determination 2009 and NGER Auditor Registration Instrument 2010 - to the more recent revisions by October 2019. During this period, the legislation was revised a number of times and each revision was accompanied by a small-scale consultation. In this episode, the Department aimed to determine the roles and responsibilities for each category. We followed the continuous changes made to the three categories, as well as the roles and responsibilities allocated to auditors in each category. We first analysed how changes were made by the Department in response to the various forms of criticism it had received from accounting and non-accounting lobbyists in the previous episode. We then followed the controversies regarding how the legislative descriptions were acted upon and criticised by auditors, and finally, how the rigidity of the rules was modified by the Department. In addition, we followed the number of registrations in each and multiple categories by individual registered greenhouse and energy auditors (RGEAs) and their firms. By doing so, we filtered the Top 8 greenhouse and energy auditing firms with the greatest number of registrations in Category II and III by 2014, given that only auditors registered in those categories can act as team leaders.

In following the whole process, retrospectively, we identified 12 representative actors (see Table 2). We analysed what they had (or had not) claimed and criticised. These representatives included the Department, AUASB, and professional bodies, firms, and individuals from the three professions. It is worth noting that in Trial I, a submission was received from the joint accounting bodies (JAB), including CPA Australia, ICAA (Institute of Chartered Accountants Australia) and NIA (National Institute of Accountants). In Trial II, this alliance was extended 
to include all six accounting firms in the Top 8, and they named themselves the Carbon Assurance Task Force (CATF). This approach sat in stark contrast to the approach adopted by engineering and environmental actors, who made individual submissions in the consultation processes. Distinctively, the engineering firm NCSI submitted two comment letters but neither lobbyist knew of the other submission's existence ${ }^{16}$.

Insert Table 2 about here

To confirm our understanding of the trials and obtain more updated information regarding Trial III, from 2012 to 2017, the first author conducted interviews with four key representative actors - the Department, the AUASB, a Category I technical and II RGEA with engineering background (engineering GREA), and a Category I technical and II RGEA with experience in sustainability assurance (environmental GREA) (see Table 2). The interviewee from the Department had previously been in charge of the administration of greenhouse and energy auditors, and the interviewee from the AUASB was a former member who worked together with the Department in developing the NGER Audit legislations. Although the AUASB has a broader mandate, our interviewee from the AUASB viewed her/himself as a representative of the accounting profession. Of the two practitioner interviewees, the engineering RGEA expressed strong resistance to the accounting profession and had himself been actively involved in all the consultations. The environmental RGEA was less resistant towards the accountants: in his own words "somewhere in the middle". This auditor had also worked in a Big 4 firm during 2015-2016 because of its acquisition of his previous firm. The interviewees were contacted either directly, using their public email address, or through social networks established from seminars or LinkedIn. Each interview ran from one to two hours. Except for one face-to-face interview with the engineer in 2012, all interviews were conducted by telephone or Skype. The interviews were semi-structured. During the interview, some general questions were asked in terms of the auditor categories and relevance of auditor expertise, as well as the responsibility of different roles. In addition, a case-by-case discussion was conducted based on our knowledge of each interviewee's identity and role in trials. For example, during the interview with the former regulator, we asked a question regarding their relationship with auditors. During the interview with the non-accounting practitioners, we asked about their opinion regarding the accountant's expertise. The interviews were audiorecorded or documented using written notes, and then were transcribed by the first author. The transcript was later emailed to each interviewee for confirmation and no disagreement was received.

Having now described the theoretical concepts, data, methods, and actors mobilized in order to explore the construction of professional identities, roles, and responsibilities within the context of jurisdictional disputes, the remainder of this paper is dedicated to the empirical storyline that surrounded the development of the regulation of the auditor categorisation project in Australia.

16 This was learned from our interview with one lobbyist and via email from the other. 


\section{$5 \quad$ Trial I 2008: Dividing technical experts and lead auditors}

\subsection{What are they not?}

In October 2008, the Department published Consultation Paper One, in which external audits underpinning both the NGER Act and the CPRS were proposed as a "key compliance measure" (DCC 2008b, p. 6). It stated that the quality of emissions data underpinning the CPRS would need to be of "investment grade ${ }^{17}$ to provide the market with a sound foundation for decision making" (DCC 2008b, p. 2). It implied that the carbon market that Australia aimed to establish was going to take a similar shape to the stock market (MacKenzie 2009). Given that "no one really knew what the auditor will be doing when it was developed" (former regulator interview 2017), the external audits were clarified by the Department in relation to financial and environmental audits, highlighting the ways in which it was similar, and the ways it was different:

External audits [...] are clearly distinguishable from financial or environmental audits, reviews and other procedures of an audit nature, as they do not comprise the same information. However, many of the essential principles, basic procedures and understanding of corporate financial information, environmental and quality audits may be relevant to external audits of emissions and energy information (DCC 2008b, p. 6, emphasis added).

Regarding auditor accreditation, the Department also analysed the four possibilities of using existing accreditation systems including: 1) the Australian Securities and Investments Commission (ASIC) - accreditation for Registered Company Auditors (RCAs); 2) the Registrar Accreditation Board and the Quality Society of Australasia International (RABQSA International) - accreditation for Lead Environmental Auditors (LEAs); 3) ISO 14065:2006 accreditation for bodies, not individuals; and 4) accreditation by professional bodies. However, none of them could meet the complete skill sets needed to perform the duties defined within the NGER Act or CPRS (DCC 2008b). In particular, while RCAs would need technical expertise from engineering professionals, LEAs lacked experience with assurance engagements (DCC 2008b). Moreover, given that ASIC was focused on accounting professionals, it could present a barrier for non-accountants. Therefore, the Department considered taking on the role of registering and administering auditors.

Two categories of auditors thus were proposed - "lead auditor" and "technical expert" (DCC 2008b, p. 14). Lead auditors were required to obtain leadership skills to "select and lead a multi-disciplinary, professional audit team, understand an expert's work, and be able to credibly accept responsibility for expressing an assurance opinion" (DCC 2008b, p. 14). The Department also proposed specifying different categories of lead auditor because the scope of the audit was "potentially broad" (DCC 2008b, p. 12). Technical experts were acknowledged to need technical skills and experience, including "financial accounting/auditing, engineering or science, or for a more specific area such as coal-fired power stations" (DCC 2008b, p. 12).

\subsection{Whose expertise is more relevant?}

According to Power (1997a, p. 142), a new type of audit is never completely new; instead, it is "a new configuration of realignment" of the particular portfolios of existing multidisciplinary competencies. The negative form of discourse used to define the external audits as what they were not, rather than what they were, gave rise to trials of strength among the three professional

\footnotetext{
${ }^{17}$ In accordance with the CPRS Green Paper which stated aligning financial and emissions reporting and verification system, the Department further enhanced this proposal through the term "investment grade". However, it was the first and only time this term was used in the consultation process due to the failure to rectify the CPRS.
} 
lobbyists in testing claims to relevance of expertise for lead auditors. Despite the Department's interpretation of "financial accounting/auditing" as parts of technical expertise paralleling environmental science and engineering (DCC 2008b, p. 12), our analysis shows that most of the lobbyists assumed that financial auditors would be limited to the 'financial' components of the external audits, environmental auditors to 'environmental' and engineers to 'technical'. Trial I was revolved around consolidating and ranking technical, environmental and financial expertise. Below we present the three distinctive translations made in Trial I.

\subsubsection{Technical and environmental rather than financial}

Engineering lobbyists argued that the "external audit" was essentially a matter of technical, not financial, measurement. As ACEA claimed:

The auditing process pertaining to the NGER Act should be focussed on fundamental raw data collection and measurement methods, rather than how the business being audited may wish to allocate the data through its various corporate structures. [...] Operational control of carbon emissions is a technical/systems matter rather than a legal or accounting matter (ACEA submission 2008, p. 3, emphasis added).

This opinion was seconded by engineering firms. In its submission, Carbon Intelligence linked financial auditors' expertise to bad debt provision, which in its opinion was irrelevant to value the volume of different types of emissions. As claimed:

We have found that the challenge in greenhouse audits is not the numbers analysis, which requires considerable professional expertise in corporate financial audits. [...] Just as a financial lead auditor must have a good sense of what accounts receivable value and bad debt provisioning would be expected for an operation with a certain turnover in a particular industry; so should a greenhouse emissions auditor have a good sense of what tonnage of emissions of what gases would be expected for an operation with a certain production tonnage and staffing in a particular industry (Carbon Intelligence submission 2008, p. 2, emphasis added).

In addition, ACEA was concerned that the expertise of non-accounting practitioners was discounted by the Department:

We believe that there is the potential for the proposed external auditing arrangements to undervalue the contribution that environmental, engineering and similar practitioners make to greenhouse and energy reporting (ACEA submission 2008, p. 3, emphasis added).

Compared to the concern of the ACEA, individual engineers expressed more emotion in questioning the competence of financial auditors as well as the Department:

I bet that none of the people who wrote the NGER External Audit Consultation Paper or any of the people in the consultation venue that I attended had ever measured greenhouse gas emissions in their lives or had any idea of how they would do so if asked. If I was in charge of an audit I wouldn't sign off on anything produced by a lawyer, an accountant or a related audit paper shuffler. What do they know about how to measure greenhouse gas? (Individual engineer submission 2008, p. 2, emphasis added).

\subsubsection{More environmental and technical than financial}

Unlike engineers, rather than excluding financial auditors, environmental lobbyists agreed that the "external audits" were multidisciplinary in nature. However, they emphasized the importance of environmental practitioners - especially LEAs with "a central role" because of their scientific competence and established experience in climate change related projects: 
Both sets of competencies are needed to provide assurance. [...] We propose the Government establishes a strong environmental framework to underpin a robust auditing platform and the development of a Lead Auditor process, as detailed in this submission. The Institute believes that environmental practitioners have a central role in undertaking greenhouse gas and energy audits (EIANZ submission 2008, p. 2, emphasis added).

As a profession, we have extensive expertise in greenhouse gas and energy auditing, assessment and climate change science (EIANZ submission 2008, p. 2).

GHD, an environmental firm, also emphasized the difference between the proposed external audits and financial audits:

[e]xternal audits of emissions and energy under the NGER Act or future legislation to underpin the CPRS would need to be distinguishable from mainstream audits, in particular financial audits (GHD submission 2008, p. 4, emphasis added).

Engineers" "significant contribution" was acknowledged; however, due to their "limited audit experience", engineers should be subordinated under their leadership, as GHD claimed:

A technical specialist in gas turbines with limited audit experience could provide a significant contribution to an audit team if he/she is working under the guidance of an experienced lead auditor (GHD submission 2008, p. 4, emphasis added).

\subsubsection{More financial and technical than environmental}

In dramatic contrast to the silence of engineers and environmental lobbyists, all the accounting lobbyists echoed the Department's ambition for "investment grade" emissions data for the CPRS and advocated aligning financial reporting and the NGER framework. As JAB claimed:

There are financial implications for all emitters, particularly the large emitters and reporting entities which are listed entities and involved in the capital markets. It is thus important for the NGER framework to be aligned as much as possible with the assurance framework that applies to the financial reporting framework (JAB submission 2009, p. 1, emphasis added).

Through the rhetoric of "investment grade", Ernst and Young argued that external audits were "expected to be the same as for a financial statement audit" (e.g., Ernst \& Young submission 2009 , p. 2). Meanwhile, it seconded the Department's claim that the external audits should be distinguishable from environmental audits because the environmental auditors" "system audit" approach was of little direct relevance:

Certified Environmental Auditors - This accreditation is focused on systems audits and our view is that it is not directly suited to the needs of the NGER Act or the CPRS (Ernst \& Young submission 2008, p. 7, emphasis added).

In particular, accounting lobbyists believed that "determining the risk of material misstatement" was critical to external audit, while engineers could play an "assisting" role:

Technical greenhouse gas emission and energy capabilities are required to assist the assurance specialist in determining the risk of material misstatement and in providing assurance on compliance with the application of measurement criteria of the underlying data (Ernst \& Young submission 2008, p. 2, emphasis added). 
In addition to supporting the use of ISAE/ASAE 3000 which is broadly applicable to sustainability assurance, accounting lobbyists referred to a set of standards established in financial auditing to navigate their shortcomings on the subject matter expertise and justify the superior assurance quality they could provide. These included, for example, ISA/ASA 620 Using the Work of An Expert, APES 320 Quality Control for Firms, and ASA 220 Quality Control for Audits of Historical Financial Information (Ernst \& Young submission 2008).

\subsection{Discussion of Episode I}

Trials to define the contextual meaning of the new type of audit began. At first, no one knew exactly what the new type of external audit would be, but each of the professional lobbyists wanted to emphasize the relevance of their own skill sets (Huggins et al. 2011). While environmental lobbyists stressed the importance of climate change science required in differentiating with financial audit, accounting lobbyists tended to favor a risk-based financial audit approach as compared to a system-based audit adopted by environmental auditors. Nevertheless, both groups agreed that external audits underpinning the NGER Act and proposed CPRS were multidisciplinary in nature and engineers should be included (as technical experts) under their subordination. On the other hand, engineering lobbyists argued for the critical importance of technical expertise in collecting and measuring emissions data, which was completely different to the measurement or estimation of financial data.

Power (1997a, p. 124) suggested that market competition is sustained "by a form of interpretative competition in the form of claims to expertise". Trials of strength in Trial I revolved around testing claims of similarity and difference between their own and their counterparts' expertise (Power 1997). In so doing, all attempted to consolidate and rank the relevance of three areas of expertise - technical, environmental, and financial. Despite its aim to include mixed expertise, the term "investment grade" implicitly indicated the Department's intention to rely more on accountants than others for these audits. This rhetorical device automatically allowed the accounting lobbyists to align explicit interest with the Department. In addition, a set of established auditing and assurance standards produced for financial auditing and sustainability assurance were also recruited by accountants to navigate around any perceived technical obstacles (Latour 1987; Gendron et al. 2007). These standards can also be viewed as inscriptions in ANT terms because they enabled "an action at a distance" (Robson 1992, p. 685; Gendron et al. 2007; Qu \& Cooper 2011). On the other hand, engineering lobbyists were dissatisfied with having their role restricted to technical experts and strongly resisted the involvement of financial auditors. They started to question the competence of the Department and its bias towards accountants in developing the regulation. This confirms that in allocating social roles, those disadvantaged within a trial will criticise both the dominant actor and the organiser of the trial (Bourguignon \& Chiapello 2005). From the trials of strength in this episode, it is also evident that no agreement could be reached among the three professional groups regarding the ranking of relevance of expertise.

\section{Trial II 2009: Categorising greenhouse and energy auditors}

\subsection{Who should be registered in which categories?}

Given the dispute regarding the relevance of expertise to lead auditors in Trial I, the Department initiated another consultation in July 2009. In Consultation Paper Two, the "external audit" was formally named as "greenhouse and energy audit" (DCC 2009b). Notably, "investment grade", which justified the importance of accountants in the previous episode, was not 
mentioned because the CPRS had been postponed as a result of severe criticism ${ }^{18}$ (AAP 2009). In terms of auditor accreditation, the Department decided that only individuals intending to accept appointments as team leaders needed to apply for registration with GEDO, while team members (including experts) did not have to be registered (DCC 2009b). To set up multidisciplinary team structure, the Department was committed to:

$[\mathrm{u}]$ sing commonly understood language and concepts to enable a broader range of auditing professionals to participate in audits under the Act, including financial auditors and existing greenhouse gas verifiers (DCC 2009b, p. 14, emphasis added).

One such instance of using "commonly understood language" was evidenced in defining two levels of engagement, i.e., verification and assurance, with the latter including both reasonable and limited assurance (DCC 2009b). The Department admitted that the term "verification" was used because "engineers used it under the ISO 14064-3 in most of the greenhouse gas schemes internationally" (former regulator interview 2017). A verification engagement, according to the Department, "results in a report on factual findings and does not include the opinion of the team leader" (DCC 2009b, p. 37). This was essentially identical to "agreed-upon procedures" used by accountants rather than the meaning of verification used by engineers in environmental audits. In ISO 14065, verification has the same meaning as assurance. By referring to terminological devices and ranking strengths according to auditors' experience with verification and assurance, the Department attempted to allocate three professional experts into three categories:

Category I auditors will need to have knowledge and experience in audit activities like verification or agreed-upon procedures. Category II and III auditors require team leadership and knowledge and experience in leading audit teams and providing assurance (DCC 2009b, p. 24, emphasis added).

Notably only auditors registered in Category II and III can act as team leaders, which also indicates continuous professional development for registered auditors. In particular, Category II required an auditor to have 200 days of "relevant audit experience" in the preceding three years, including at least 50 days spent leading an audit team (DCC 2009b, p. 24). Category II RGEAs can apply to be upgraded into Category III after completing two greenhouse and energy audits. During our interview, the former regulator explained for what and why these three categories were designed:

Category I was set up to really give the technical auditors who were not assurance auditors a category they can apply for and somewhere they can be recognised. Category II was always assurance auditors. I think Category III was basically to recognise really good assurance auditors, particularly I guess it was something the big accounting firms wanted, because they wanted a way to be separated. They are "really good gold-star" auditors - that was [what] the Category III [was] meant to be (former regulator interview 2017, emphasis added).

To control audit quality, the Department also specified the roles and responsibilities of team leaders and peer reviewers. The Department emphasized that "they [team leaders] cannot just be the signatory to the audit conclusion" (DCC 2009b, p. 15) and "all the activities must be conducted by the audit team leader" (DCC 2009b, p. 16). This requirement was more consistent with the way non-accounting practitioners lead a team. In addition, the Department also

18 The proposed CPRS bill was rejected twice by Parliament and on 27 April 2010, then Prime Minister Kevin Rudd announced that the implementation of the CPRS should be deferred for an indeterminate period while developing the related audit regulation (DCCEE 2010). 
proposed a role of "peer reviewer" whose responsibility was to "evaluate the judgements made by audit team leaders" (DCC 2009b, p. 36). Similar to the team leader, the Department required that a peer reviewer prepare a report with his/her name disclosed.

\subsection{Are these rules fair and appropriate?}

According to Bourguignon and Chiapello (2005), for this kind of categorisation to function effectively it needs to be both complete and controllable. In this case it was especially related to appropriateness and fairness, i.e., what is (not) used and measured versus what should not (should) be used and measured. However, objectivity is decided by trials of strength, which are associated with heterogeneous resources that support the underlying claims (Latour 1987). The two interessement devices (Callon 1986) - terminological device and quantifiable measurement - used by the Department to classify auditors and define the responsibilities of team leaders and peer reviewers triggered the second episode of trials of strength, which reflected concern, resistance, and criticism from all the three expert groups, but for conflicting reasons.

\subsubsection{Criticism of "relevant audit experience"}

Using 200 days of "relevant audit experience" as a criterion for Category II registration was strongly opposed by all engineering (except for Carbon Intelligence) and environmental (except for GHD) lobbyists ${ }^{19}$. They complained that the measurement was too stringent and embedded a clear preference for financial auditors. In particular, engineering lobbyists believed it could potentially exclude all engineers from being registered as team leaders in these audits. In his submission, our interviewee (the engineering RGEA) criticised the framework as "highly biased":

Only in Australia the audit framework as well as NGER is highly biased towards financial auditing models (engineering RGEA submission 2009, p. 1, emphasis added).

Using an analogy, he argued that greenhouse and energy audits were "treated more like a financial check for a carbon balance sheet" (engineering RGEA submission 2009, p. 2). In an effort to counter the Department's proposal, EIANZ re-emphasised their belief that financial audit was of little relevance, while experience of environmental audits was more relevant and transferable to these audits:

Individuals with direct exposure to experience in environmental auditing and assessment would have a more transferable experience set should direct greenhouse and energy experience be lacking (EIANZ submission 2009, p. 5, emphasis added).

Some engineers also questioned the need for categorisation:

The need to distinguish between three categories of auditors is unclear. There appears to be no such requirement in other established international Greenhouse auditing schemes (NCSI submission 2009, p. 2).

If auditors must be classified, NCSI suggested the Department establish two categories: greenhouse gas (GHG) Auditor and Lead GHG Auditor.

\footnotetext{
${ }^{19}$ GHD and Carbon Intelligence had already established their reputation in the field of greenhouse gas related assurance and verification.
} 


\subsubsection{Concern over the term "verification"}

The term "verification" was concerned by the accounting lobbyists ${ }^{20}$. CATF argued that using "audit" as a synonym for "verification" might be especially misleading because no assurance was provided in a verification engagement (CATF submission 2009).

Apparently, CATF understood that behind the term "verification" was a gesture of conciliation toward engineers. In representing the interest of engineers, it warned the Department that the term would be foreign to engineers as well given its meaning was inconsistent to that in ISO standards:

As a term used in engineering or a quality management system, verification is the "act of reviewing, inspecting, testing, etc. to establish and document that a product, service, or system meets the regulatory, standard, or specification requirements" (CATF submission 2009, p. 7).

CATF strongly urged that the term be replaced by "agreed-upon procedures" to benefit the users as well as engineers. In contrast, non-accounting lobbyists in general were insensitive to auditing terminology. Most of them did not realise the differences between the "verification" proposed by the Department and that used in ISO standards. However, we still noted one point of confusion being raised:

There is no need to differentiate between an assurance and verification engagement. In greenhouse gas areas, verification audits are conducted to provide assurance (limited or reasonable) (engineering RGEA submission 2009, p. 1, emphasis added).

\subsubsection{Resistance to double control over team leaders}

In addition to their sensitivity to terminology, accounting lobbyists also questioned the rules exerted on team leaders and peer reviewers. First, they believed it was impractical for team leaders to personally engage in overseeing every audit procedure. To persuade the Department not to require this, CATF referred to the newly published quality control standard ASQC $1^{21}$ :

The current requirement for the team leader to oversee the work that each team member is undertaking is unrealistic in practical terms. ASQC 1 requires adequate supervision and review responsibilities to be put in place (CATF submission 2009, p. 26, emphasis added).

While CATF emphasised that the team leaders' responsibility was about "supervision" rather than "oversight", Ernst \& Young did not differentiate the nuances of the two terms but underlined team leaders' personal activities in key steps, rather than all steps:

It appears that the audit team leader must personally conduct all steps of the assurance procedures. We recommend that this be revised so that the audit team leader has an oversight, review and direction role, with only key steps requiring personal activity (e.g., agreeing engagement terms, approving the audit plan and finalising and signing the assurance report) (Ernst \& Young submission 2009, p. 2, emphasis added).

\footnotetext{
20 This was similar to accountants' sensitivity to the term "verification" in sustainability assurance (Owen \& O'Dwyer 2005).

${ }^{21}$ ASQC 1 Quality Control for Firms that Perform Audits and Reviews of Financial Reports and Other Financial Information, and Other Assurance Engagements was effective from January 2010 (AUASB 2009). Notably, APES 320, mentioned by the accounting actors in the previous lobbying effort, was amended in May 2009 because of its overlap with the proposed ASQC 1 (APESB 2013).
} 
Second, in terms of the role of "peer reviewer", CATF suggested changing its title to "quality control reviewer" according to ASQ1 (CATF submission 2009, p. 26). CATF was concerned about the potential conflicting roles played by the team leader and peer reviewer. For example, it argued that the peer reviewer should neither perform additional assurance procedures nor form another opinion or conclusion; rather, any issue should be resolved between the peer reviewer and team leader before the opinion or conclusion was made. CATF also opposed disclosing the name of the peer reviewer as well as the reviewer's report because of "the confusion it could create as to the relative roles and responsibilities of the peer reviewer vis-àvis the engagement team leader" (CATF submission 2009, p. 19).

The sensitivity of CATF regarding what peer reviewers should and should not do was distinctive to the advocates from environmental auditors (e.g., GHD submission). Notably, GHD proposed that peer reviewers should be at minimum Category II auditors.

\subsection{Discussion of Episode II}

In this episode, three categories of greenhouse and energy auditors were designated by the Department as a solution to settle the professional dispute, given no agreement could be reached regarding the nature of the greenhouse and energy audit in Trial I. Through classifying three categories of greenhouse and energy auditors and proposing varied roles and responsibilities, the Department expected to rank three expert groups in order through a trial in categorisation (Callon 1986; Bourguignon \& Chiapello 2005). As the Department did not want to be perceived as biased (Martinov-Bennie \& Hoffman 2012, p. 200), terminological devices (especially the term "verification") were deliberately used to enrol engineers, as well as differentiating them from accountants. On the other hand, although "investment grade" was no longer relevant due to political uncertainty with the ratification of the CPRS, the measurement device of 200 days of "relevant audit experience" still showed the intention of the Department to place financial auditors (especially those from the Big 4 firms) in the top category. While the Department attempted to appease both engineers and accountants, neither of the two interessement devices (Callon 1986) could work for their intended purpose without being perceived as biased by its counterparty. The Department and the trial were criticised, therefore, by both accountants and non-accountants, but for conflicting reasons. Notably, auditing terminology and the new quality control standard played an important role in supporting the accounting lobbyists' claim of expertise (Gendron et al. 2007), and their interpretation of the "supervisory" role of team leaders in contrast to the "oversight" role defined by the Department.

To enrol is also to control (Latour 1987), and the Department expected to control audit quality through regulating team leaders' behavior. Accounting lobbyists' concern about the responsibilities defined for team leaders and peer reviewers revealed their commitment to retain a hierarchical team structure in delegating routines to subordinates (Power 1997a). Compared to the explicit criticism of bias claimed by engineers, accounting lobbyists exhibited their rhetorical strength in claiming bias more implicitly. For example, in counter-enrolling and persuading the Department not to use the term "verification", accounting lobbyists attempted to represent the interest of engineers through a strategy which could be depicted as "they (engineers) don't want it, why do you?" This strategy could be viewed as an extension of what Latour (1987) depicted as "I want it, why don't you?" This also set a stark distinction to engineers' strategy of exclusion in the first episode. While Bourguignon and Chiapello (2005) conceptualises how criticism could contribute to enhancing trials, it would be interesting to see how criticisms from opposing sides were settled in the next episode. 


\section{Trial III 2010-2019: Designating roles for each category}

\subsection{Determining three categories and main roles}

Finally, the legislative framework, including the NGER (Audit) Determination, and NGER Auditor Registration Instrument, were adopted in December 2009 and January 2010 respectively, after a longer than expected consultation process. Despite the accounting lobbyists' resistance to using the term "verification" and their warning of the practical confusion it may cause to engineers, the term was still accepted and specified as an engagement type, while Category I was further divided into two sub-categories - technical and nontechnical, by referring to "verification" and "agreed-upon procedures", respectively (Australian Government Attorney-General's Department 2010). By doing so, accountants and engineers in Category I could be easily identified. In terms of Category II, instead of requiring 200 days of "relevant audit experience in the preceding three years", the measurement was replaced by 700 hours of "relevant assurance experience in the preceding five years" (Australian Government Attorney-General's Department 2010, p.10). This change was apparently aimed at allowing non-accounting experts to be registered and act as team leaders.

While attempting to comfort non-accounting professions, especially engineers, the Department also addressed some concern from accountants regarding the responsibilities of team leaders and peer reviewers, but the changes were not substantial. Although the Department followed CATF in replacing the word "oversee" with "supervise" to describe the role of team leaders, it did not reduce the level of their personal involvement, instead requiring them to carry out an audit engagement in addition to planning and providing an opinion/conclusion:

1) The audit team leader must be personally involved in preparing for and carrying out the audit, and in the preparation of the audit report.

2) The audit team leader must supervise the work that each audit team member is undertaking in carrying out the audit (Australian Government ComLaw 2009, p. 8, emphasis added).

In terms of peer reviewers, although the Department insisted on using the title "peer reviewer", one interviewee told us that the accounting profession conflated the role with that of a "quality control review partner" or a "second-resigning partner" (former regulator interview 2017). Following the suggestion of the accounting lobbyists, the duty of the peer reviewer in an audit team was limited to reviewing key documents and the audit report (Australian Government ComLaw 2009). However, the Department insisted that the name of the peer reviewer and details of the outcome of the evaluation be included in an audit report. The former AUASB member interviewed in this study commented:

That is not required for all engagements [financial audits], while they [DCCEE] required peer review always. And partly because they are dealing with new engagements, they want to have extra quality control (former AUASB member interview 2016).

\subsection{Allocating roles and responsibilities}

While the three categories (we should perhaps say four, as Category I was split into two subcategories) were established, the next task for the Department was to allocate each category to various roles and responsibilities. Although rules were set up in terms of the duties of team leaders and peer reviewers, trials of strength did not end as these rules were still subject to testing for compliance or resistance due to conflicting interests and constraints (Tremblay \& Gendron 2011). Trials of responsibility (Latour 1987) between accountants and nonaccountants also continued in deciding who did which job. 


\subsubsection{Category II and team leader}

Although accountants established their leadership without much surprise, their contribution was subject to scrutiny as their counterparties came to know more about their practice. During the interviews, the two non-accounting Category I and II RGEAs, including one with work experience in a Big 4 firm, criticised that:

They (Category II RGEAs in Big 4 firms) don't contribute much. Sometimes they did the plan. The Big 4 firms charge $\$ 600-800$ per hour; it is too expensive (engineering RGEA interview 2012).

In accounting firms, lead auditors are always partners. They are very busy and not very handson. In fact, often the partner will not be very involved although they are capable, but someone junior or more junior [will] do the work, which I don't think it is a good way to run an engagement. My feeling is that lead auditors will probably not be involved, particularly in the Big 4 firms" (environmental RGEA interview 2016).

From their comments, we learn that accountant team leaders may not follow the rule of "carrying out" an audit (Australian Government ComLaw 2009). As this observation became known, in March 2015, the Department requested, in a training workshop held for all RGEAs, that team leaders must be allocated with at least 7 percent of workload for an audit job (CER 2015a). The reason, as explained by our Department interviewee who was directly involved in this requirement, was that:

It is somewhat because the team leaders in the accounting firms are normally partners who are quite busy. You will notice the big difference in the amount of hours. The accounting firms would follow that 7 to 8 percent recipe while the partner just allocates the work and reviews the work coming to them. The engineering firms definitely will not. The audit team leader in the engineering firms might do 50 percent of the work, they would do site visits, they would do analytics, which the partners in the accounting firms will not do (former regulator interview 2017, emphasis added).

Comparing the 7 percent of work done by accounting team leaders with 50 percent by engineers, the compromise made by the Department showed its acquiescence with the way an accountant lead a multidisciplinary team.

\subsubsection{Category II and peer reviewer}

Peer review was also found to become a contentious issue in practice because the Department found that many of the peer reviewers "lacked assurance experience" and in particular, their skills of documentation inspection was quite poor (CER 2015b, p. 8). Surprisingly, the Department noted that the Big 4 firms tended to replace the role of a peer reviewer with a technical expert (former regulator interview 2017), because AUASB required a peer reviewer to have "complementary expertise" to the team leader (AUASB 2012a, p. 19). Therefore, in contrast to the AUASB's request, the Department required the person to have "equivalent or greater expertise" to challenge the team leader's professional judgement (CER 2015a). Compared to the 7 percent workload required for a team leader, 3-4 percent of workload was allocated to the peer reviewer in a team (CER 2015a).

In the more recent consultation 2017, the Department required that a peer review must be performed by a Category II RGEA or RCA (DEE 2017). This seemed consistent with the GHD's suggestion in the second consultation. However, this requirement created another 
dilemma, because most of the engineering firms that had Category II registration only had one person and it was impractical to borrow another one. The two active engineering lobbyists, Carbon Intelligence and our engineer interviewee (who then joined another engineering firm), both strongly opposed the rule, asserting it was "discriminatory":

This expectation of requiring minimum two category 2 auditors to even bid for work could be discriminatory as [few] non-financial auditing firms: 1) could comply [with] this level of stringent requirements; 2) could be very expensive or not affordable to maintain two category 2 auditors (engineering RGEA submission 2017, p. 1).

Our interviewee warned that this rule would potentially eliminate engineering firms from undertaking any assurance engagement and result in the monopoly of the Big 4 firms (engineering RGEA submission 2017). Despite the strong criticism from engineers, however, no better solution could be provided by the Department to balance the conflicts, and the change was still made in legislation and has been applied since July 2017 (Australian Government ComLaw 2017).

\subsubsection{Category I and technical expert}

As anticipated by accountants, "verification" also confused non-accounting practitioners in practice. Engineers then realised that its meaning was inconsistent with that defined in the ISO standards. The former AUASB member critiqued the lack of knowledge that the Department demonstrated, and commented that "it just makes nobody understand":

The people we worked with had never been involved in auditing. They did not understand the terminology implications for the accounting profession anyway and so they took the term "verification" coming from ISO as evidence that they have looked at the ISO as well. The $\mathrm{DCC}(\mathrm{EE})$ at the time (because they were not engineers or accountants) did not really appreciate what the terminology meant but had just taken the word "verification" and decided to use it like agreed-upon procedures. It just did not help the engineers. So it was not beneficial for engineers to use that term. It just makes nobody understand (former AUASB member interview 2016, emphasis added).

Despite their disagreement, accountants accepted to use the term "verification" in order to "be pragmatic" (former AUASB member interview 2016). In terms of the criticism, our interviewee from the Department admitted that the term made everyone struggle including themselves:

Yes, Australians confused it by giving them different names. And in fact, the engineers struggled about it because these terms are not the terminology they are used to. Even we struggled a little bit with how to use the verification audit in the way they are written (former regulator interview 2017).

The reason behind this peculiarity, as the Department member speculated, was due to the confrontations between accountants and engineers:

One of the things I remember when you are looking at the NGER scheme and policies behind the stuff is at that point of time [there was] a kind of negotiated rules and legislations mainly between the financial auditors and the more technical ISO auditors. There are bits of legislation that are a little bit weird (former regulator interview 2017). 
In September 2015, technical vs. non-technical were no longer being differentiated and this was also reflected in the revised NGER Auditor Registration Instrument 2016 (CER 2016). The Department also clearly indicated that a Category I auditor could normally act as a team member or technical expert, but only in the absence of a Category II RGEA could he/she lead a verification audit (CER 2018). To this end, Category I lost its proposed significance and became of little value or benefit because initially no registration was required for team members (including technical experts). As most of the engineers only obtained registration in this category, their roles seemed to be locked into technical work rather than team leadership. From 22 October 2019, Category I registration ceased (CER 2019), despite the concern from environmental firms that it should still be maintained as "a stepping stone" to achieve Category II status (e.g., GHD submission 2019, p. 11). Anyhow, those who had already obtained Category I would maintain their registration status.

\subsection{Discussion of Episode III}

This episode began with the modifications made by the Department in legislation in responding to various criticisms it faced in Trial II. According to Bourguignon and Chiapello (2005), when criticism is perceived as strong, the designer of the trial would tighten it up by making a partial or radical change; when criticism is perceived to be weak, it would be ignored. An example is seen in the significant change made to the measurement device used for Category II registration in response to the strong claim of bias from non-accounting lobbyists. On the other hand, although the term "verification" was opposed by the accounting lobbyists because the way it was defined was neither appropriate nor consistent, the Department did not change it. The reason, as shown in our analysis, was not because the accountants' basis of opposition was not strong enough to support their claim (indeed, their claim of bias was quite rhetorical), but when claims of expertise from accountants met claims of bias from engineers, the latter prevailed. The term was chosen by the Department despite the risk of confusion in practice to deliberately demonstrate their fairness by giving engineers a category distinguishable from accountants. However, with the roles revised for Category I auditors and the recent abolition of registration as well as practical constraints in obtaining a qualified peer reviewer (an extra Category II RGEA) in many small engineering firms, most of the engineering RGEAs were locked into the role of technical experts or members.

In defining the roles and responsibilities of team leaders and peer reviewers in the first edition of the legislation, although the Department followed some of the accounting lobbyists' suggestions, these changes were rather superficial. Consequently, continuous trials regarding compliance/resistance to these rules were triggered. In contrast with their pragmatism regarding the term "verification", accountants ignored or manipulated the descriptive rules in practice. First, accountants were noted to be noncompliant with the rule of "carrying out" an audit, but, although accountants' "orchestration" style (Power 1997a, p. 125) of leadership was also criticised by the other parties regarding who actually did the job, the multi-lateral trials of strength and responsibility finally ended with the acquiescence and compromise of the Department (Shapiro \& Matson 2008; Malsch \& Gendron 2011). Although we did not conduct interviews with individual accounting RGEAs, this could imply that the logic of resistance toward any change in their traditional form of supervision was much stronger than the logic of compliance (Tremblay \& Gendron 2011). Second, while quality control standards were recruited to claim their relevance to leadership in previous trials, accountants ironically replaced the function of a peer reviewer with the role of a technical expert by playing games with the "complementary expertise" required by the AUASB. Given the dialectical nature of enrolment, the Department inevitably faced an ongoing dilemma in mediating the conflicting 
interests and goals encountered while maintaining its control over the enrollment process (Latour 1987).

\section{Epilogue - What happened to the registration and Category III?}

Auditor registration started in May 2010 and there were 123 individual auditors registered in one or both categories. Since then, the total registration of greenhouse and energy auditors increased to 173 in 2012 and reached 200 in 2013, but then dropped to 106 by 2017. By 2019, the total registration has reduced to 91, with 35 auditors registering in Category I, 11 in Category II and 45 in both Category I and II. This shrinking market can be attributed to the failure of the CPRS due to "a very changeable five years (of) legislation" ensuing from political turmoil (environmental RGEA interview 2016) ${ }^{22}$. This may have been because "unlike the UK, Australia has never had climate consensus" (Butler 2017). Table 3 shows some detailed figures of registration from accounting and non-accounting firms as of December 2012. It was not unexpected that engineers and environmental auditors only obtained 29 percent of Category II registration, with the rest occupied by partners and senior auditors from the Big 4 firms (see Table 3).

Insert Table 3 about here

Although the registration considered only individuals rather than firms, the Top 8 firms accounted for nearly 50 percent of Category I registrations, two-thirds of Category II, and 100 percent of Category III auditors by July 2014 (see Table 4). These included the Big 4 firms plus two second-tier firms (BDO and RSM Bird Cameron), and GHD and Carbon Intelligence were the only two non-accounting firms in the Top 8. Notably KPMG and Ernst \& Young had the most auditors in every category, including Category I technical, indicating their ability to attract multidisciplinary practitioners.

Insert Table 4 about here

Significantly, the uptake of Category III registration was much slower. In August 2012, only two auditors were registered, one from RSM Bird Cameron, the other from GHD. By December 2012, this had grown minimally to four, shared equally by the same two firms. By July 2014, only 14 auditors got the registration and all of them were from the Top 8 (see Table 4). Registration for Category III did not work as planned and it was described as "silly", "useless" (environmental RGEA interview 2016), "absurd", and "too complicated" (former AUASB member interview 2016). In September 2015, this category was formally removed (CER 2016). Most tellingly, the Department realised that those Big 4 "gold-star auditors" were actually not

\footnotetext{
22 After the failure of the CPRS, two other schemes were passed and implemented under the multi-party Gillard Government, which required external audits to be conducted by RGEAs. One was the Carbon Farming Initiative (CFI) Act with external audits required similar to those under the NGER Act (CER 2012). The other was the Carbon Pricing Mechanism (CPM) with external audits similar to the previously proposed CPRS from 2013 (AUASB 2012b). However, as the Labor Party lost the election to the Liberal Party in September 2013, CPM was abolished from 2015 (CER 2014).
} 
interested in this top category; rather, Category III registered less (or even the least) experienced auditors:

They are "really good gold-star" auditors - that was what the Category III was meant to be. But in actual fact it didn't work. What ended up happening was because all audits could be led by either Category II or III, nobody needs Category III. What you found out was that the betterquality and more experienced assurance auditors, most of them did not bother to apply for Category III because they did not need to, they already have the reputation. Whereas the new auditors who did not have much experience, the moment they did two audits then they straight away became Category III. So, what actually ended up is some of the auditors with the least experience became Category III (former regulator interview 2017, emphasis added).

The Department also realised that it was complexity rather than number of audits that reflected the real auditor experience, therefore using "two audits" as a benchmark device for upgrading was problematic:

Someone has done a lot of audits but all just little ones, whereas someone from Deloitte has not done many audits but the audits he has done were really big complex NGER audits or CPM audits. So he probably is more experienced. This is another thing with the Category III that we realised, that the number of audits did not have any reflection on the actual experience and expertise (former regulator interview 2017).

Our interviewee added:

Everyone wants to register for every category but actually they are not using those categories, so it looks good for their marketing. In actual fact it might be just one or two people doing all that work. Quite a lot of auditors have not done any work or might only have done one or two audits (former regulator interview 2017, emphasis added).

These findings also led to another conclusion: there was no need to register firms in the future because the number of registrations in a firm was irrelevant:

Say, $\mathrm{PwC}$ does not have many auditors registered whereas another firm registers a lot of people, such as GHD. It does not really make a lot of difference. They still probably do just as many audits because they have as many audit managers (former regulator interview 2017).

In reflecting upon its relationship with auditors during the regulatory process, the former regulator admitted that the Department was accused of bias all the time especially by engineers and accountants, and its role was to "pull them together":

Being a big public service, we definitely get accused of favoritism all the time and that's across all the roles. That is part of being the regulator, unfortunately. Particularly there were conflicts between engineers and accountants. The engineers think we favor the accountants, and the accountants think we favor the engineers. My role was to pull them together. Whether they are best friends or not, it does not matter, the quality of audits is what is more important because if the audits have no good quality, then nobody could get any work. So we all have to help each other out. And they would to a degree. It [competition] used to be very bad, not too bad now, but you still find under time a competition, I guess it is just a friendly competition (former regulator interview 2017, emphasis added).

In assigning audit jobs and appointing auditors, the Department also found itself in the odd position, trying to maintain both a regulatory role and a friendly relationship with auditors who worked as its contractors: 
It was a weird relationship when we regulate the auditors. We have to keep that a bit of separation. But they are also contractors and a lot of them work closely with us and they like friends to work with. And even the fact that we quite often on working groups together and things like that. So it was always weird if we were asked to going out for dinner, then we would think "ohh, but I shouldn't do that because I am the regulator". Sometimes the whole working group went out [to] dinner together, I just sit on the corner of the table and don't talk to you. It was a little weird (former regulator interview 2017, emphasis added).

\section{Reflection and concluding remarks}

This paper explores the regulatory process of how a pool of greenhouse and energy auditors from engineering, environmental, and financial auditing backgrounds was established with a multidisciplinary team structure by the Australian government through terminology and measurement devices for categorisation. By using the concepts of trials (Callon 1986; Latour 1987) and criticism (Bourguignon and Chiapello 2005), the issues of how the identities, roles, and responsibilities of three expert groups were classified, distributed, negotiated, and reshaped in constructing a mix of greenhouse and energy auditing expertises was explored. The government's categorisation program (as an important enrolment strategy aimed at mediating interprofessional rivalries) triggered more trials given the conflicting interests and goals, as reflected by: confrontations among three expert lobbyists in testing each other's relevance of expertise for the leading role; conflicts between the Department and each of the expert groups (especially engineers and accountants) in testing the appropriate and fair criteria in classifying greenhouse and energy auditors, and; controversies between the Department and the accounting profession in testing compliance or resistance to the descriptive rules for team leaders and members' (e.g., peer reviews) responsibilities. In the end, the categorisation program failed to achieve its initial purpose: the significance and value of Categories I and III were discounted and finally both ceased accepting new registrations or were abolished completely, with Category II being the only active one which enrolled experts from all three professional backgrounds, though the real audit job was only allocated to a few auditors. The registration finally became loosely coupled with auditor expertise.

Our main contributions to the literature lie in the following three aspects:

First, previous cases in studying interprofessional competition in new audit fields presented how accounting actors struggled to legitimise the relevance of their expertise in competing with non-accountants and/or enrolling the auditee, either successfully (e.g. Gendron \& Barrett 2004; Gendron et al. 2007) or not (e.g. Andon et al. 2014). However, this study is concerned with the leading role of accountants being presumed by the regulator - partly the cause of the trials of strength - rather than the outcome of the trials. As was intended from the outset, the Department made it possible for all three professions to be included in the new field for greenhouse and energy audits, and through its process of public consultations, it provided a space for all three professional groups to debate and settle their interprofessional disputes over the shape of the audits and auditors. While this process is ongoing, the current regulation privileges financial auditors' experience in auditing and assurance over the specific technical and environmental expertise of engineers and environmental scientists in the subject matter. This study makes a unique contribution by focusing on the question of how engineers and environmental auditors sought to secure an equivalent role through claims of expertise and bias, though de facto, unsuccessfully. Theoretically, trials of strength between accountants' claims to relevance of expertise and engineers' claims of bias to expertise constituted one of the important characteristics of the interprofessional competitions under our analysis. Moreover, in defining 
the "hierarchical relations between different bodies of expertise" (Power 1997b, p. 82), Power (1997a, p. 125) proposed three negotiation strategies used by accountants in establishing "lead expertise" in environmental audit, including advancing claims of similarity and difference; promoting the role of audit as an abstract body of knowledge, and; advocating the subordination of science to accounting. Our study shows that these strategies, especially the first two, were no longer unique to accounting actors but also applicable to other professional lobbyists in trials of strength. In fact, environmental auditors explicitly argued that their expertise was more transferable to greenhouse and energy audits, while comparatively, given their lack of assurance experience, engineers became the most disadvantaged group in the trials.

Second, our study contributes to reconsidering some taken-for-granted claims which historically legitimized accountants as a profession for self-regulation. Consistent with extant literature, the accounting profession demonstrated its lobbying strength through aligning explicit interest with the regulator, anchoring relevance of expertise through various inscriptions and devices, and counter-enrolling the regulator through rhetorical strategies (Cooper \& Robson 2006; Gendron et al. 2007; Suddaby et al. 2007; O'Dwyer et al. 2011). Although the profession's relative success is not unexpected, we show that there was conflict between accountants and the regulator especially regarding the scope and responsibility of team leaders. Our findings suggest that the accounting profession was keen to sustain an orchestration style of supervision in delegating routine and technical work to subordinates (Power 1997a). While delegating routines to subordinates (e.g., engineers) once established the legitimacy of accountants such as in management accounting and environmental auditing (Armstrong 1985; Abbott 1988; Power 1997a), their traditional form of supervision and lack of personal engagement were subject to be challenged and revisited in constructing a new audit field, given the different styles of team leadership by accountants and non-accountants (Latour 1987). Although the trial between accountants and the Department in testing the appropriateness of regulatory discourse was ended by the acquiescence and compromise of the Department, the contribution of accounting team leaders was not convincing enough to persuade its counterparties. Meanwhile, accountants were confident of their auditing expertise and in many cases, they tried to educate the non-expert regulator about auditing through terminological devices and quality control standards. For example, accountants made a great effort to explain and clarify the term "verification" in different standards, and rhetorically admonish the Department for the potential risk of causing practical confusion to users as well as engineers. While their claimed competence in methodology and quality control were also supported by some Australian authors (Simnett et al. 2009b; Huggins et al. 2011; Green \& Li 2012; Martinov-Bennie \& Hoffman 2012), our evidence shows how accountants actually manipulated and sacrificed their quality control function, given their concern over the conflicting roles of the team leader and peer reviewer, which cast further doubt over the accounting profession's market reputation and ability to self-regulate (Malsch \& Gendron 2011; O'Regan \& Killian 2014).

Third, our paper contributes to the ongoing debate regarding professional identity and the role of the regulator (the non-expert) in constructing new audit expertise. Interprofessional identities were defined in this study through trials of strength regarding what expertise actors had, and what role they should take, by considering claims to relevance of expertise. While Skærbæk's (2009) case study revealed how conflicting identities were sustained by auditors in making government efficiency auditable, our study shows how conflicting roles were created by the regulator in mediating interprofessional competitions. While previous research was focused on the oversight role of the government in regulating the accounting profession with contested findings about their power relationships (Malsch \& Gendron 2011; Canning \& 
O'Dwyer 2013; O'Regan \& Killian 2014), our study sheds light on the multiple roles played by the regulator where its relationships with three expert groups added new characteristics to the study of resistance and criticism. Although prior research (Bourguignon \& Chiapello 2005) conceptualizes different responses to criticism (including resistance), this paper articulates what happened when two opposing streams of criticism met, and how their influence shaped auditor identities and responsibilities. Through an analysis of how concern, criticism, and resistance from three professional representatives were acted and reacted upon by the regulator, our nuanced findings in terms of the meanings of "verification" and "supervision" reflected the dilemma the Department faced in maintaining a perceived objectivity in regulatory decisionmaking.

Finally, given the global climate emergency, where GHG emissions disclosure and assurance are increasingly becoming an important political response to address the issue (Simnett et al. 2009a), our investigation of how a multidisciplinary pool of greenhouse and energy auditors was established, structured and regulated in Australia provides a good opportunity to further explore the controversial role of accountants and auditing expertise with new characteristics (Power 1997a; Huggins et al. 2011; Andon et al. 2015; Channuntapipat et al. 2019; Farooq \& de Villiers 2019; Channuntapipat et al. 2020). While the development of this regulation is ongoing, our findings provide some useful insights into unintended practical and social consequences, given the unpredictability of regulatory process (Tremblay \& Gendron 2011). It will be interesting to follow where this multidisciplinary structure of auditor registration will lead in the future, given the uncertainty of Australian politics and the potential engagements of these RGEAs in other unregulated assurance fields such as sustainability or integrated reporting. Will it lead to further professional domination of the field by accountants (e.g., Gendron \& Barrett 2004; Gendron et al. 2007)? Or hybridisation of a new profession (e.g., Kurunmäki 2004), especially given that AUASB 3410 is also applicable to non-accounting RGEAs who are also identified as "assurance practitioners", similar to accounting RGEAs by the AUASB (AUASB 2011)? The recent proposal of a new auditing profession by the Brydon Report in the UK in December 2019 also provides further possibilities for this new trend internationally. Future research regarding the contractual relationship between the Department and auditors would be worthwhile to follow. It will also be interesting to investigate questions such as how the same level of assurance engagements is conducted differently by accounting and nonaccounting RGEAs (e.g., limited assurance), and how the traditional financial auditing concepts (e.g., professional judgement) are understood by non-accounting practitioners (Canning et al. 2019; Channuntapipat et al. 2019; Farooq \& de Villiers 2019). Importantly, the lessons learned in Australia could provide insights into many similar regulatory regimes in multidisciplinary fields. 


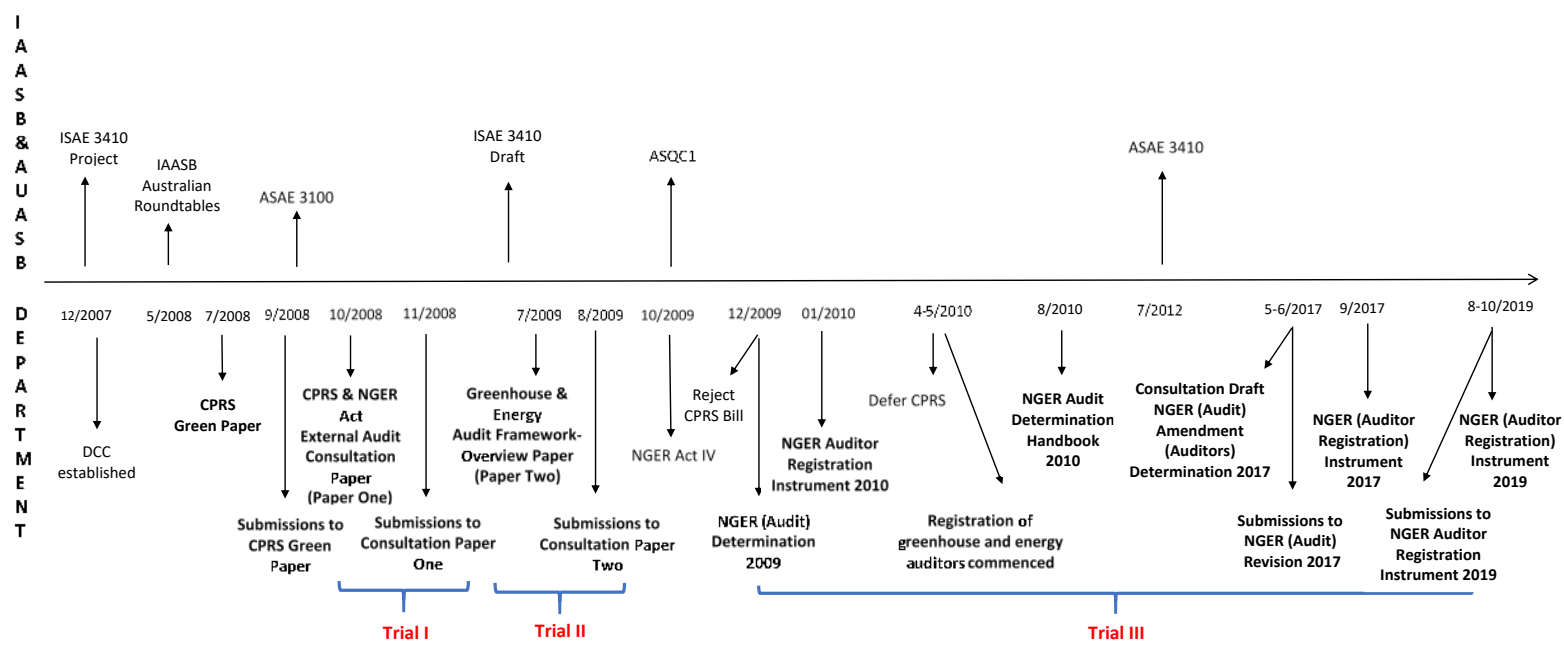

Figure 1: Milestones in developing the NGER (Audit) Legislative Framework from 2007 to 2019

\begin{tabular}{|c|c|c|c|}
\hline & Episode I & Episode II & Episode III \\
\hline & 2008-2009 & $2009-2010$ & 2010-2019 \\
\hline The Department & $\begin{array}{l}\text { NGER Act } 2007 \text { and CPRS } \\
\text { External Audit Consultation } \\
\text { Paper (Consultation Paper One) }\end{array}$ & $\begin{array}{l}\text { NGER Act } 2007 \text { and CPRS } \\
\text { Greenhouse and Energy Audit } \\
\text { Framework Overview Paper } \\
\text { (Consultation Paper Two) }\end{array}$ & $\begin{array}{l}\text { NGER Audit Legislation including: } \\
\text { NGER (Audit) Determination 2009-2017; } \\
\text { NGER Auditor Registration Instrument } \\
\text { 2010-2019; } \\
\text { Auditor Workshop 2015; } \\
\text { Consultation Draft NGER (Audit) } \\
\text { Amendment (Auditors) Determination } \\
2017 \text {; } \\
\text { Consultation NGER Auditor Registration } \\
\text { 2019; } \\
\text { Auditor registration data 2010-2019; } \\
\text { Interview with the Department }\end{array}$ \\
\hline Professional actors & $\begin{array}{l}\text { Submissions from: } \\
\text { engineering professional body, } \\
\text { firms and individuals; } \\
\text { environmental auditor } \\
\text { professional body and firms; } \\
\text { JAB* and accounting firms }\end{array}$ & $\begin{array}{l}\text { Submissions from: } \\
\text { engineering firms and individuals; } \\
\text { environmental auditor professional } \\
\text { body and firms; } \\
\text { CATF**; Ernst and Young }\end{array}$ & $\begin{array}{l}\text { Submissions from: } \\
\text { engineering firms and individuals; } \\
\text { environmental firms; } \\
\text { Interviews with the AUASB and two non- } \\
\text { accounting RGEAs }\end{array}$ \\
\hline Purpose & $\begin{array}{l}\text { Define the nature of the external } \\
\text { audits; } \\
\text { Classify lead auditors and } \\
\text { technical experts }\end{array}$ & $\begin{array}{l}\text { Define three categories of } \\
\text { greenhouse and energy auditors; } \\
\text { Propose responsibilities of the team } \\
\text { leader and members }\end{array}$ & $\begin{array}{l}\text { Allocate different role(s) to each } \\
\text { category; } \\
\text { Determine responsibilities of the team } \\
\text { leader and members }\end{array}$ \\
\hline \multicolumn{4}{|c|}{ * JAB: Joint Accounting Bodies, including CPA Australia, ICAA, and NIA. } \\
\hline $\begin{array}{l}\text { CATF: Carbon As } \\
\text { ornton, and PKF) }\end{array}$ & - & - & $\mathrm{t}$ \\
\hline
\end{tabular}

Table 1: The key documents and data in each of the three trial episodes 


\begin{tabular}{|c|c|c|c|c|c|c|}
\hline Actors & Identities & \begin{tabular}{|c|} 
Activity in \\
Trial I
\end{tabular} & $\begin{array}{c}\text { Activity in } \\
\text { Trial II }\end{array}$ & \begin{tabular}{|c|} 
Activity in \\
Trial III
\end{tabular} & $\begin{array}{l}\text { Ranking of } \\
\text { registration }\end{array}$ & $\begin{array}{l}\text { Interview } \\
\text { time }\end{array}$ \\
\hline The Department & $\begin{array}{l}\text { Australian regulator } \\
\text { and administrator }\end{array}$ & $\mathrm{x}$ & $\mathrm{x}$ & $\mathrm{x}$ & & 2016 \\
\hline AUASB & $\begin{array}{l}\text { Australian Standard } \\
\text { Setting Board }\end{array}$ & $\mathrm{x}$ & $\mathrm{x}$ & $\mathrm{x}$ & & 2016 \\
\hline Ernst \& Young & Big 4 firm & $\mathrm{x}$ & $\mathrm{x}$ & $\mathrm{x}$ & Top 8 & \\
\hline $\mathrm{JAB}$ & \begin{tabular}{|l|} 
Joint Accounting \\
Professional Bodies \\
\end{tabular} & $\mathrm{x}$ & & & & \\
\hline CATF & $\begin{array}{l}\text { Carbon Assurance } \\
\text { Task Force }\end{array}$ & & $\mathrm{x}$ & & \begin{tabular}{|c|} 
including all the 6 \\
accounting firms in \\
the Top 8
\end{tabular} & \\
\hline EIANZ & $\begin{array}{l}\text { Environmental auditor } \\
\text { professional body }\end{array}$ & $\mathrm{x}$ & $\mathrm{x}$ & & & \\
\hline GHD & Environmental firm & $\mathrm{x}$ & $\mathrm{x}$ & $\mathrm{x}$ & Top 8 & \\
\hline $\begin{array}{l}\text { A sustainability } \\
\text { professional }\end{array}$ & Category I \& II RGEA & & & $\mathrm{x}$ & & 2017 \\
\hline ACEA & $\begin{array}{l}\text { Engineering } \\
\text { professional body }\end{array}$ & $\mathrm{x}$ & & & & \\
\hline Carbon Intelligence & Engineering firm & $\mathrm{x}$ & $\mathrm{x}$ & $\mathrm{x}$ & Top 8 & \\
\hline NCSI & $\begin{array}{l}\text { Engineering firm with } \\
\text { a Category I \& II } \\
\text { RGEA }\end{array}$ & & $\mathrm{x}$ & $\mathrm{x}$ & & 2012 \\
\hline An engineer & Individual practitioner & $\mathrm{x}$ & & & & \\
\hline
\end{tabular}

$\mathrm{x}$ : Participate

Table 2: Key representative actors identified in three trial episodes

\begin{tabular}{|c|c|c|c|c|c|c|}
\hline \multirow{2}{*}{ Firms } & \multirow{2}{*}{$\begin{array}{l}\text { Number of } \\
\text { firms }\end{array}$} & \multicolumn{2}{|c|}{ Number of Category I } & \multirow{2}{*}{$\begin{array}{l}\text { Number of } \\
\text { Category II }\end{array}$} & \multirow{2}{*}{$\begin{array}{l}\text { Number of } \\
\text { Category III }\end{array}$} & \multirow{2}{*}{$\begin{array}{l}\text { Total } \\
\text { registration }\end{array}$} \\
\hline & & technical & $\begin{array}{c}\text { non- } \\
\text { technical }\end{array}$ & & & \\
\hline \multirow{2}{*}{ Accounting } & 15 & 21 & 41 & 51 & 2 & 70 \\
\hline & $18 \%$ & $17 \%$ & $61 \%$ & $71 \%$ & $50 \%$ & $40 \%$ \\
\hline \multirow{2}{*}{ Non-accounting } & 69 & 101 & 26 & 21 & 2 & 103 \\
\hline & $82 \%$ & $83 \%$ & $39 \%$ & $29 \%$ & $50 \%$ & $60 \%$ \\
\hline \multirow{2}{*}{ Total } & 84 & 122 & 67 & 72 & 4 & 173 \\
\hline & $100 \%$ & $100 \%$ & $100 \%$ & $100 \%$ & $100 \%$ & $100 \%$ \\
\hline
\end{tabular}

Table 3: Comparison of the accounting and non-accounting registration as of December 2012 


\begin{tabular}{|l|r|r|r|r|r|}
\hline Firms & $\begin{array}{c}\text { Category I } \\
\text { technical }\end{array}$ & $\begin{array}{c}\text { Category I } \\
\text { non- } \\
\text { technical }\end{array}$ & Category II & Category III & $\begin{array}{c}\text { Total } \\
\text { RGEAs }\end{array}$ \\
\hline KPMG & 15 & 18 & 16 & 1 & 31 \\
\hline Ernst \& Young & 9 & 8 & 13 & 4 & 15 \\
\hline PwC & 3 & 9 & 8 & 1 & 10 \\
\hline Deloitte & 4 & 5 & 5 & 1 & 6 \\
\hline GHD Pty Ltd* & 5 & 2 & 3 & 3 & 5 \\
\hline RSM Bird Cameron & 0 & 3 & 4 & 2 & 5 \\
\hline BDO & 0 & 4 & 3 & 1 & 5 \\
\hline Carbon Intelligence** & 4 & 3 & 2 & 1 & 4 \\
\hline Total of Top 8 & 40 & 52 & 54 & 14 & 81 \\
\hline Total registration & 116 & 77 & 81 & 14 & 172 \\
\hline Percentage of Top 8 & $\mathbf{3 4 \%}$ & $\mathbf{6 8 \%}$ & $\mathbf{6 7 \%}$ & $\mathbf{1 0 0 \%}$ & $\mathbf{4 7 \%}$ \\
\hline * Environmental service firm ** Engineering firm \\
\hline
\end{tabular}

Table 4: Top 8 greenhouse and energy audit firms in 2014

\section{Acknowledgement}

We want to express our deep gratitude to Yves Gendron (Editor) and two anonymous reviewers for their insightful feedback and suggestions. Special thanks also go to Corinne Cortese and Jane Andrew for their valuable comments and contributions to the earlier versions. Shirley Xu would also like to thank Jan Mouritsen, Ed Errington, Mary Kaidonis and Geoffrey Heath for their inspirations and help during the long journey. 
Abbreviations

ACEA

APES

APES 320

ASA

ASA 220

ASA 620

ASAE

ASAE 3410

ASQC 1

AUASB

CATF

CDP

CER

CFI Act

CPA

CPM

CPRS

DCC

DCCEE

DEE

EIANZ

EITE

EU ETS

GEDO

GHG

GRI

IAASB

ICAA

IFAC

ISAE

ISAE 3000

ISAE 3100

ISAE 3410

ISO

ISO 14064-3

ISO 14065-3

LEA

JAB

NGER Act

NGERS

NIA

NSW GGAS

RGEA

RCA

\section{Appendix I}

Association of Consulting Engineers Australia

Accounting Professional and Ethical Standard

Quality Control for Firms

Australian Auditing Standard

Quality Control for Audits of Historical Financial Information

Using the Work of an Expert

Australian Standard on Assurance Engagements

Assurance Engagement on Greenhouse Gas Statement

Quality Control for Firms that Perform Audits and Reviews of Financial

Reports and Other Financial Information, and Other Assurance

Engagements

Australian Auditing and Assurance Standard Board

Carbon Assurance Task Force

Carbon Disclosure Project

Clean Energy Regulator

Carbon Credit (Carbon Farming Initiative) Act

Certified Professional Accountants

Carbon Pricing Mechanism

Carbon Pollution Reduction Scheme

Department of Climate Change

Department of Climate Change and Energy Efficiency

Department of the Environment and Energy

Environmental Institute of Australia and New Zealand

emissions-intensive trade exposed

European Union Emission Trading Scheme

Greenhouse and Energy Data Officer

Greenhouse gas

Global Reporting Initiative

International Auditing and Assurance Standards Board

Institute of Chartered Accountants Australia

International Federation of Accountants

International Standard on Assurance Engagements

Assurance Engagement Other than Audits or Reviews of Historical Financial

Information

Compliance Engagements

Assurance Engagement on Greenhouse Gas Statement

International Organization for Standardization

Greenhouse Gases - Part 3: Specification with guidance for the validation and verification of greenhouse gas assertions

Greenhouse gases - requirements for greenhouse gas validation and

verification bodies for use in accreditation or other forms of recognition

Lead Environmental Auditor

Joint Accounting Bodies

National Greenhouse and Energy Reporting Act

National Greenhouse and Energy Reporting System

National Institute of Accountants

New South Wales Greenhouse Gas Reduction Scheme

Registered Greenhouse and Energy Auditor

Registered Company Auditor 


\section{References}

AAP (2007). Australia ratifies Kyoto Protocol, Australian Assoiciated Press, 3 December 2007.

AAP (2009). Changes to ETS win for businesses, says chamber of commerce, Australian Associated Press General News, 5 May 2009.

Abbott, A. (1988). The system of professions, Chicago: University of Chicago Press.

Andon, P., Free, C. \& O'Dwyer, B. (2015). Annexing new audit spaces: challenges and adaptations. Accounting, Auditing and Accountability Journal, 28 (8), 1400-1430.

Andon, P., Free, C. \& Sivabalan, P. (2014). The legitimacy of new assurance providers: Making the cap fit. Accounting, Organizations and Society, 39 (2), 75-96.

APESB (2013). Annual Review of APEA 320 Quality Control for Firms reissued in May 2009. Accounting Professional \& Ethical Standards Board.

Armstrong, P. (1985). Changing management control strategies: the role of competition between accountancy and other organisational professions. Accounting, Organizations and Society, 10 (2), 129-148.

AUASB (2008). The 29th AUASB Board Meeting Minutes, http://www.auasb.gov.au/Archive/BoardMeetings.aspx, accessed 12 January 2012.

AUASB (2009). ASQC 1 - Quality Control for Firms that Perform Audits and Reviews of Financial Reports and Other Financial Information, and Other Assurance Engagments. Australian Government ComLaw.

AUASB (2011). Board Meeting Summary Paper: Report on Roundtable Meeting on ISAE 3410 Assurance Engagement on Greenhouse Gas Statements, http://www.auasb.gov.au/BoardMeetings.aspx, accessed 7 June 2013.

AUASB (2012a). GS 021 Engagements under the National Greenhouse and Energy Reporting Scheme, Carbon Pricing Mechanism and Related Scheme, http://www.auasb.gov.au/Pronouncements/AUASB-Guidance-Statements.aspx, accessed 7 June 2013.

AUASB (2012b). Project Plan: Assurance Engagements on Greenhouse Gas Statements, http://www.auasb.gov.au/search-

result.aspx?search=Assurance\%20Engagements\%20on\%20Greenhouse $\% 20 \mathrm{Gas} \% 20$ Statemen ts, accessed 22 December 2012.

AUASB (2013). Standards on Assurance Engagements, http://www.auasb.gov.au/Pronouncements/Standards-on-Assurance-Engagements.aspx, accessed 15 May 2013.

Australian Government Attorney-General's Department (2007). National Greenhouse and Energy Reporting Act 2007, Australian Government Attorney-General's Department.

Australian Government Attorney-General's Department (2010). National Greenhouse and Energy Reporting (Auditor Registration) Instrument 2010, Australian Government Attorney-General's Department.

Australian Government ComLaw (2008). National Greeenhouse and Energy Reporting Act 2007.

Australian Government ComLaw (2009). National Greenhouse and Energy Reporting (Audit) Determination 2009. Australian Government ComLaw.

Australian Government ComLaw (2017). National Greenhouse and Energy Reporting (Audit) Determination 2009.

Boiral, O. \& Gendron, Y. (2011). Sustainable development and certification practices: lessons learned and prospects. Business Streategy and the Environment, 20, 331-347.

Boltanski, L. \& Thévenot, L. (1999). The sociology of critical capacity. European Journal of Social Theory, 2 (3), 359-377.

Bourguignon, A. \& Chiapello, E. (2005). The role of criticism in the dynamics of performance evaluation systems. Critical Perspectives on Accounting, 16 (6), 665-700.

Briers, M. \& Chua, W. F. (2001). The role of actor-networks and boundary objects in management accounting change: a field study of an implementation of activity-based costing. Accounting, Organizations and Society, 26 (3), 237-269.

Burritt, R. L. (1999). Commonwealth greenhouse challenge - the reporting and verification process. Australian Journal of Environmental Management, 6 (1), 44-51. 
Butler, M. (2017). How Australia bungled climate policy to create a decade of disappointment, The Guardian, 4 Jul 2017. https://www.theguardian.com/australia-news/2017/jul/05/howaustralia-bungled-climate-policy-to-create-a-decade-of-disappointment, accessed 10 Jan 2020.

Callon, M. (1986). Some elements of a sociology of translation: domestication of the scallops and the fishermen of St Brieuc Bay, in Law, J (Ed.) Power, Action and Belief: A New Sociology of Knowledge, (pp. 196-233), London: Routledge \& Kegan Paul.

Canning, M. \& O'Dwyer, B. (2013). The dynamics of a regulatory space realignment: Strategic responses in a local context. Accounting, Organizations and Society, 38 (3), 169-194.

Canning, M. \& O'Dwyer, B. (2016). Institutional work and regulatory change in the accounting profession. Accounting, Organizations and Society, 54 (1), 1-21.

Canning, M., O'Dwyer, B. \& Georgakopoulos, G. (2019). Processes of auditability in sustainability assurance - the case of materiality construction. Accounting and Business Research, 49 (1), 127.

Carter, C., Spence, C. \& Muzio, D. (2015). Scoping an agenda for future research into the professions. Accounting, Auditing \& Accountability Journal, 28 (8), 1198-1216.

CER (2012). Carbon Farming Initiative, http://www.cleanenergyregulator.gov.au:80/CarbonFarming-Initiative/Pages/default.aspx, accessed 20 May 2017.

CER (2014). Carbon Pricing Mechanism, http://www.cleanenergyregulator.gov.au/Carbon-PricingMechanism/Pages/default.aspx, accessed 20 August 2014.

CER (2015a). Audit Team Structure - Presentations from Auditor Workshops - March 2015, http://www.cleanenergyregulator.gov.au/NGER/Pages/previous\%20events/Presentations\%20f rom\%20Auditor\%20Workshop\%20-\%20March\%202015.aspx, accessed 2 Feburary 2017.

CER (2015b). NGER Audit Framework 2014-15 - Presentations from Auditor Workshop - March 2015, http://www.cleanenergyregulator.gov.au/NGER/Pages/previous\%20events/Presentations\%20f rom\%20Auditor\%20Workshop\%20-\%20March\%202015.aspx, accessed 15 March 2017.

CER (2016). National Greenhouse and Energy Reporting (Auditor Registration) Instrument 2016. Australian Government Clean Energy Regulator.

CER (2018). Register of auditors, www.cleanenergyreporting.gov.au, accessed 26 July 2018.

CER (2019). Greenhouse and energy auditor registration guideline, http://www.cleanenergyregulator.gov.au/Infohub/Audits/information-for-auditors/how-toregister-as-an-auditor, accessed 1 December 2019.

Channuntapipat, C., Samsonova-Taddei, A. \& Turley, S. (2019). Exploring diversity in sustainability assurance practice: Evidence from assurance providers in the UK. Accounting, Auditing \& Accountability Journal, 32 (2), 556-580.

Channuntapipat, C., Samsonova-Taddei, A. \& Turley, S. (2020). Variation in sustainability assurance practice: an analysis of accounting versus non-accounting providers. The British Accounting Review, 52 (2), 1-17.

Cooper, D. J. \& Robson, K. (2006). Accounting, professions and regulation: Locating the sites of professionalization. Accounting, Organizations and Society, 31 (4-5), 415-444.

DCC (2007). Australian Government Department of Climate Change Website, http://web.archive.org/web/20071224113728/http://www.climatechange.gov.au/, accessed 7 June 2013.

DCC (2008a). Carbon Pollution Reduction Scheme Green Paper, http://www.climatechange.gov.au/en/publications/cprs/green-paper/cprs-greenpaper.aspx, accessed 30 May 2011.

DCC (2008b). The NGER and CPRS External Audit Consultation Paper, http://www.climatechange.gov.au/reporting/publications/pubs/external-audit.pdf, accessed 5 June 2009.

DCC (2008c). National Greenhouse and Energy Reporting Guidelines, http://www.climatechange.gov.au/reporting/guidelines/index.html, accessed 29 September 2009.

DCC (2009a). The EITE Guideline Paper, http://www.climatechange.gov.au/publications/cprs/eite/eite-guidance-paper.aspx, accessed 4 April 2009. 
DCC (2009b). Greenhouse \& Energy Audit Framework Overview Paper, http://www.climatechange.gov.au/government/initiatives/national-greenhouse-energyreporting/audit.aspx, accessed 23 December 2010.

DCCEE (2010). Carbon Pollution Reduction Scheme, http://www.climatechange.gov.au/cprs/, accessed 9 February 2012.

DCCEE (2013). Australian Government Department of Climate Change and Energy Efficiency: The Intergovernmental Panel on Climate Change (IPCC) Fifth Assessment Report (AR5), http://www.climatechange.gov.au/publications.aspx, accessed 15 May 2013.

DEE (2017). National Greenhouse and Energy Reporting (Measurement) Amendment (Energy) Determination 2017 and National Greenhouse and Energy Reporting (Audit) Amendment (Auditors) Determination 2017 Departmental Commentary, http://www.environment.gov.au/climate-change/climate-science-data/greenhouse-gasmeasurement/nger/consultation/national-greenhouse-and-energy-reporting-schemeamendments-2017, accessed 23 May 2018.

EIANZ (2010). Certified Environmental Practitioner Scheme, https://www.eianz.org/instituteprograms/certified-environmental-practitioner-scheme, accessed 12 March 2010.

Farooq, M. B. \& de Villiers, C. (2019). The shaping of sustainability assurance through the competition between accounting and non-accounting providers. Accounting, Auditing \& Accountability Journal, 32 (1), 307-336.

Gay, G. \& Simnett, R. (2015). Auditing and Assurance Services in Australia 6e: Mc Graw Hill Education.

Gendron, Y. \& Barrett, M. (2004). Professionalization in action: accountants' attempt at building a network of support for the WebTrust seal of assurance. Contemporary Accounting Research, $21(3), 563-602$.

Gendron, Y., Cooper, D. J. \& Townley, B. (2007). The construction of auditing expertise in measuring government performance. Accounting, Organizations and Society, 32 (1-2), 101-129.

Green, W., Huggins, A. \& Simnett, R. (2009). The experetise required for greenhouse gas assurance engagements: lessons to be learned from existing schemes and standards. The 8th Australasian Conference on Social and Environment Accounting Research (CSEAR 2009).

Green, W. \& Li, Q. (2012). Evidence of an expectation gap for greenhouse gas emissions assurance. Accounting, Auditing \& Accountability Journal, 25 (1), 146-173.

Huggins, A., Green, W. \& Simnett, R. (2011). The competitive market for assurance engagements on greenhouse gas statements: is there a role for assurers from the accounting profession? Current Issues in Auditing, 5 (2), A1-A12.

IAASB (2012). International Standard on Assurance Engagement 3410 Assurance Engagements on Greenhouse Gas Statement.

Kurunmäki, L. (2004). A hybrid profession - the acquisition of management accounting expertise by medical professionals. Accounting, Organizations and Society, 29 (3-4), 327-347.

Latour, B. (1987). Science in action: how to follow scientists and engineers through society, Cambridge, MA: Harvard University Press.

MacKenzie, D. (2009). Making things the same: Gases, emission rights and the politics of carbon markets. Accountig, Organizations and Society, 34 (3/4), 440-455.

Malsch, B. \& Gendron, Y. (2011). Reining in auditors: On the dynamics of power surrounding an "innovation" in the regulatory space. Accounting, Organizations and Society, 36 (7), 456-476.

Martinov-Bennie, N. \& Hoffman, R. (2012). Greenhouse gas and energy audits under the newly legislated Australian Audit Determination: Perceptions of initial impact. Australian Accounting Review, 22 (2), 195-207.

O'Dwyer, B., Owen, D. \& Unerman, J. (2011). Seeking legitimacy for new assurance forms: The case of assurance on sustainability reporting. Accounting, Organizations and Society, 36 (1), 31-52.

O'Regan, P. \& Killian, S. (2014). 'Professionals who understand': Expertise, public interest and societal risk governance. Accounting, Organizations and Society, 39 (8), 615-631.

Owen, D. \& O'Dwyer, B. (2005). Assurance statement practice in environmental, social and sustainability report: a critical evaluation. The British Accounting Review, 37 (2), 205-229.

Power, M. (1991). Auditing and environmental expertise: between protest and professionalisation. Accounting Auditing \& Accountability Journal, 4 (3), 30-42. 
Power, M. (1996). Making things auditable. Accounting, Organizations and Society, 21 (2-3), 289-315.

Power, M. (1997a). Expertise and the construction of relevance: accountants and environmental audit. Accounting, Organizations and Society, 22 (2), 123-146.

Power, M. (1997b). The audit society: rituals of verification, Oxford: Oxford University Press.

Power, M. (2003). Auditing and the production of legitimacy. Accounting, Organizations and Society, 28 (4), 379-394.

Qu, S. Q. \& Cooper, D. J. (2011). The role of inscriptions in producing a balanced scorecard. Accounting, Organizations and Society, 36 (6), 344-362.

Robson, K. (1992). Accounting numbers as "inscription": action at a distance and the development of accounting. Accounting, Organizations and Society, 17 (7), 685-708.

Shapiro, B. \& Matson, D. (2008). Strategies of resistance to internal control regulation. Accounting, Organizations and Society, 33 (2/3), 199-228.

Simnett, R. \& Nugent, M. (2007). Developing an assurance standard on carbon emissions disclosures. Australian Accounting Review, 17 (2), 37-47.

Simnett, R., Nugent, M. \& Huggins, A. L. (2009a). Developing an International Assurance Standard on Greenhouse Gas Statements. Accounting Horizons, 23 (4), 347-363.

Simnett, R., Vanstraelen, A. \& Wai Fong, C. (2009b). Assurance on sustainability reports: An international comparison. The Accounting Review, 84 (3), 937-967.

Skærbæk, P. (2009). Public sector auditor identities in making efficiency auditable: The National Audit Office of Denmark as independent auditor and modernizer. Accounting, Organizations and Society, 34 (8), 971-987.

SMH (2007). Australia ratifies Kyoto Protocol, The Sydney Morning Herald, 3 December 2007. http://www.smh.com.au, accessed 3 September 2009.

Suddaby, R., Cooper, J. D. \& Greenwood, R. (2007). Transnational regulation of professional services: Governance dynamics of field level organizational change. Accounting, Organizations and Society, 32 (4-5), 333-362.

Tremblay, M. S. \& Gendron, Y. (2011). Governance prescriptions under trial: On the interplay between the logics of resistance and compliance in audit committees. Critical Perspectives on Accounting, 22 (3), 259-272.

Zhou, S., Simnett, R. \& Green, W. (2016). Assuring a new market: the interplay between country-level and company-level factors on the demand for greenhouse gas (GHG) information assurance and the choice of ssurance provider. Auditing: A Journal of Practice and Theory, 35 (3), 141168. 